EUROPEAN CENTRAL BANK

EUROSYSTEM
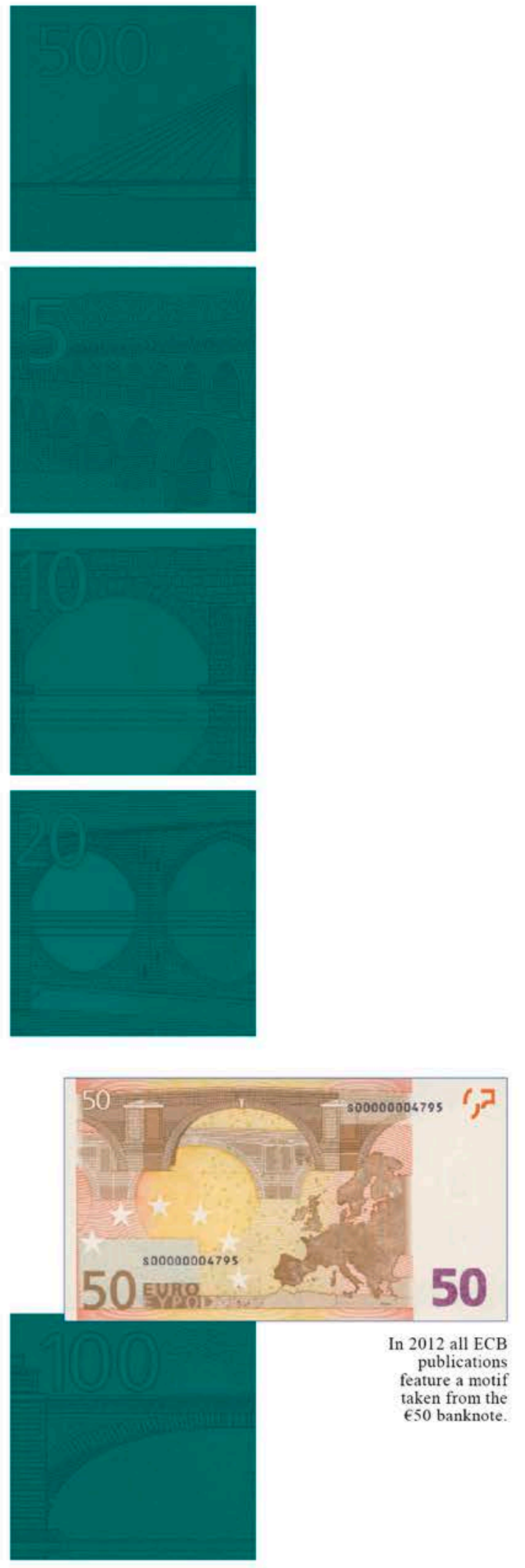

\title{
THE EURO AREA BANK LENDING SURVEY
}

$3^{\text {RD }}$ QUARTER OF 2012

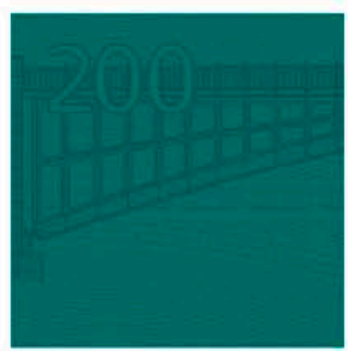

OCTOBER 2012 
(C) European Central Bank, 2012

\section{Address}

Kaiserstrasse 29, 60311 Frankfurt am Main, Germany

Postal address

Postfach 1603 19, 60066 Frankfurt am Main, Germany

\section{Telephone}

+496913440

\section{Internet}

http://www.ecb.europa.eu

\section{Fax}

+496913446000

All rights reserved. Reproduction for educational and non-commercial purposes is permitted provided that the source is acknowledged.

ISSN 1830-5989 (online) 
The results reported in the October 2012 bank lending survey (BLS) relate to changes during the third quarter of 2012 and expectations of changes in the fourth quarter of 2012. The survey was conducted between 20 September and 9 October 2012. With 131 banks participating, the response rate reached $100 \%$.

In this survey, two ad hoc questions were added to the regular questionnaire: one question addressing the impact of the financial turmoil on access to retail and wholesale funding, and one on the impact of the sovereign debt crisis on banks' funding conditions and credit standards.

\section{OVERVIEW OF THE RESULTS}

According to the October 2012 bank lending survey, the net tightening of credit standards by euro area banks for loans to enterprises increased in the third quarter of 2012 (15\% in net terms, up from 10\% in the second quarter of 2012). For loans to households for house purchase the net tightening was broadly stable in the third quarter of 2012 (12\%, after $13 \%$ in the second quarter of 2012), while the net tightening declined slightly for consumer credit (3\%, down from 7\% in the second quarter of 2012). The impact of banks' cost of funds and balance sheet constraints on the net tightening of credit standards eased in the case of loans to both enterprises and households. By contrast, risk perceptions contributed to the increase in the net tightening of credit standards on loans to enterprises in the third quarter of 2012, while in the case of loans to households for house purchase the impact of the general economic outlook and housing market prospects remained broadly unchanged.

The stronger net tightening of credit standards on loans to enterprises in the third quarter of 2012 was reflected in a further widening of margins on riskier loans to enterprises (44\%, up from $32 \%$ in the second quarter of 2012), whereas the remaining terms and conditions were broadly unchanged. Regarding housing loans, the net percentage of banks reporting a widening of margins on loans remained broadly unchanged in the case of average loans (14\% in net terms, compared with $15 \%$ in the second quarter of 2012), while the net percentage declined slightly in the case of margins on riskier loans (19\% in net terms, down from 21\% in the second quarter of 2012). The small decline in the net percentage of banks reporting a widening of margins on riskier housing loans contrasts notably with the strong increase in the case of loans to enterprises. 
Looking ahead to the fourth quarter of 2012, euro area banks expect a similar degree of net tightening in credit standards for loans to enterprises (13\% in the fourth quarter of 2012) and households (9\% in net terms for housing loans and $2 \%$ for consumer credit in the fourth quarter of 2012).

Turning to loan demand developments, euro area banks continued to report a pronounced net decline in the demand for loans to enterprises in the third quarter of 2012, and this balance was somewhat more negative than in the previous survey round (-27\%, after $-25 \%$ in the second quarter of 2012). Mergers and acquisitions and inventories and working capital were the main drivers of the more pronounced net decline in demand for loans to enterprises. By contrast, the negative impact from fixed investment on the financing needs of firms contributed somewhat less than in the previous survey round (-33\% in the third quarter of 2012, after $-36 \%$ in the second quarter of 2012). The ongoing net decline in demand for loans to households for house purchase accelerated somewhat in the third quarter of 2012 (-25\%, after $-21 \%$ in the second quarter of 2012), whereas the net decline in demand for consumer credit abated somewhat (-22\%, after $-27 \%$ in the second quarter of 2012). Looking ahead to the fourth quarter of 2012, banks expect a continued net decline in the demand for loans, both for enterprises and households, even if on balance less negative than in the third quarter of 2012.

The October 2012 BLS included two ad hoc questions. Regarding the first ad hoc question on banks' access to retail and wholesale funding in the third quarter of 2012, in contrast to the deterioration seen in the second quarter of 2012, banks reported an improvement in their access to retail and wholesale funding across all funding categories. For the fourth quarter of 2012, banks expect funding conditions to keep improving.

In response to the second ad hoc question on the impact of the sovereign debt crisis, banks indicated in the third quarter of 2012 a considerable moderation in the impact of sovereign debt tensions on banks' funding conditions. Compared with the previous quarter, the impact of the sovereign debt crisis on banks' credit standards receded somewhat in the third quarter of 2012. This development is broadly in line with the decline in the impact of the cost of funds and balance sheet constraints on banks' credit standards for loans to enterprises and households. 


\section{GENERAL NOTES}

The bank lending survey is addressed to senior loan officers of a representative sample of euro area banks. ${ }^{1}$ Its main purpose is to enhance the understanding of bank lending behaviour in the euro area. ${ }^{2}$

The questions distinguish between three categories of loan: loans or credit lines to enterprises; loans to households for house purchase; and consumer credit and other lending to households. For all three categories, questions are asked on credit standards for approving loans; credit terms and conditions; and credit demand and the factors affecting it.

The responses to questions related to credit standards are analysed in this report by focusing on the difference ("net percentage") between the share of banks reporting that credit standards have been tightened and the share of banks reporting that they have been eased. A positive net percentage indicates that a larger proportion of banks have tightened credit standards ("net tightening"), whereas a negative net percentage indicates that a larger proportion of banks have eased credit standards ("net easing"). Likewise, the term "net demand" refers to the difference between the share of banks reporting an increase in loan demand and the share of banks reporting a decline. Net demand will therefore be positive if a larger proportion of banks has reported an increase in loan demand, whereas negative net demand indicates that a larger proportion of banks has reported a decline in loan demand.

In addition, an alternative measure of the responses to questions related to changes in credit standards and net demand is included. This measure is the weighted difference ("diffusion index") between the share of banks reporting that credit standards have been tightened and the share of banks reporting that they have been eased. Likewise, regarding the demand for loans, the diffusion index refers to the weighted difference between the share of banks reporting an increase in loan demand and the share of banks reporting a decline. The diffusion index is constructed in the following way: lenders who have answered "considerably" are given a weight twice as high (score of 1) as lenders having answered "somewhat" (score of 0.5). The interpretation of the diffusion indices follows the same logic as the interpretation of net percentages.

The survey questions are phrased in terms of changes over the past three months (in this case in the third quarter of 2012) or expectations of changes over the next three months (i.e. in the fourth quarter of 2012).

Detailed tables and charts on the responses are provided in Annex 1 for the individual questions and in Annex 2 for the ad hoc questions.

\footnotetext{
${ }^{1}$ The sample group of banks participating in the survey comprises 131 banks, representing all of the euro area countries, and takes into account the characteristics of their respective national banking structures. Since the banks in the sample group differ considerably in size, the survey results are weighted according to the national shares in total outstanding euro area lending to euro area residents.

${ }^{2}$ For more detailed information on the bank lending survey, see the ECB press release of 21 November 2002 entitled "Bank lending survey for the euro area", the article entitled "A bank lending survey for the euro area" in the April 2003 issue of the ECB's Monthly Bulletin and J. Berg et al. (2005), “The bank lending survey for the euro area”, ECB Occasional Paper No 23.
} 
A copy of the questionnaire can be found at http://www.ecb.europa.eu/stats/money/surveys/lend/html/index.en.html.

\section{DEVELOPMENTS IN CREDIT STANDARDS AND NET DEMAND FOR LOANS IN THE EURO AREA}

\section{I ENTERPRISES}

\section{I.I NET TIGHTENING OF CREDIT STANDARDS FOR LOANS TO ENTERPRISES INCREASED IN THE THIRD QUARTER OF 2012}

According to the October 2012 bank lending survey, the net tightening of credit standards by euro area banks for loans to enterprises increased in the third quarter of 2012 (15\% in net terms, up from $10 \%$ in the second quarter of 2012; see Chart 1 ). At the time of the previous survey round, banks participating in the survey expected a somewhat lower degree of net tightening in credit standards for the third quarter of 2012 (10\%).

In net terms, the overall tightening of credit standards appears to have been applied more to small and medium-sized enterprises (SMEs) than to large firms. The net tightening of credit standards on loans to SMEs increased, from 6\% in the second quarter of 2012 to $11 \%$ in the third quarter of 2012, while that of credit standards on loans to large firms remained broadly stable at $17 \%$ (compared with $16 \%$ in the second quarter). Compared with the previous survey round, the net tightening of credit standards increased both for short-term loans (to 11\%, from $8 \%$ in the second quarter of 2012) and for long-term loans (to $14 \%$, from $11 \%$ ). 


\section{Chart I}

CHANGES IN CREDIT STANDARDS APPLIED TO THE APPROVAL OF LOANS OR CREDIT LINES TO ENTERPRISES

(net percentages of banks contributing to tightening credit standards)

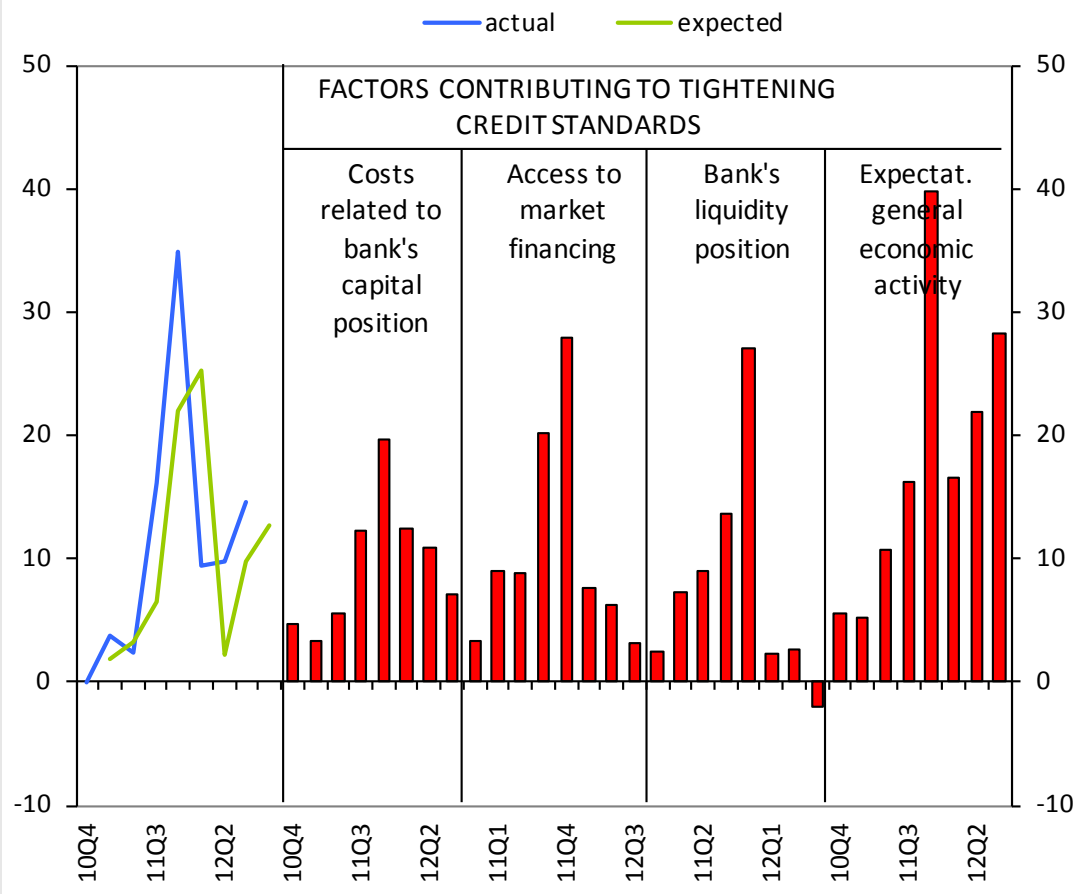

Notes: "Realised" values refer to changes that have occurred, while "expected" values are changes anticipated by banks. Net percentages are defined as the difference between the sum of the percentages of banks responding "tightened considerably" and "tightened somewhat" and the sum of the percentages of banks responding "eased somewhat" and "eased considerably". The net percentages for responses to questions related to the factors are defined as the difference between the percentage of banks reporting that the given factor contributed to a tightening and the percentage reporting that it contributed to an easing.

Turning to factors explaining developments in credit standards, the net percentage of euro area banks reporting that cost of funds and balance sheet constraints contributed to a tightening of credit standards on loans to enterprises declined in the third quarter of 2012, compared with the second quarter of 2012 (see Chart 1). In more detail, there was a moderation in the net tightening contribution from banks' capital positions (7\%, down from $11 \%$ in the second quarter of 2012), banks' access to market funding (3\%, down from $6 \%$ in the second quarter of 2012 ) and banks' liquidity position (-2\%, down from $3 \%$ in the second quarter of 2012). At the same time, the tightening impact from banks' capital positions continued to be larger than the impact of the other two factors, indicating banks' ongoing need for balance sheet adjustment. Overall, the moderation in the contribution of these factors to the net tightening of credit standards on loans to 
enterprises in the third quarter of 2012 likely reflects progress made in strengthening banks' capital positions and the improvement in financial market sentiment in the third quarter of 2012. The impact of risk perceptions on the net tightening of credit standards increased in the third quarter of 2012 compared with the previous quarter. This increase was driven mainly by expectations regarding general economic activity (28\%, after $22 \%$ in the second quarter of 2012) and industry-specific risks (30\%, after 24\% in the second quarter of 2012). By contrast, the net tightening impact of collateral risk moderated somewhat, to $5 \%$ in the third quarter of 2012 , from $8 \%$ in the previous quarter. The stronger impact of risk perceptions is likely to be related to weak economic activity and an uncertain economic outlook. Finally, competitive pressures from other banks continued to work in the direction of an easing of credit standards in the third quarter of 2012 (a net easing of 3\%, unchanged from the second quarter of 2012).

\section{Chart 2}

CHANGES IN TERMS AND CONDITIONS FOR APPROVING LOANS OR CREDIT LINES TO ENTERPRISES

(net percentages of banks reporting tightening terms and conditions)

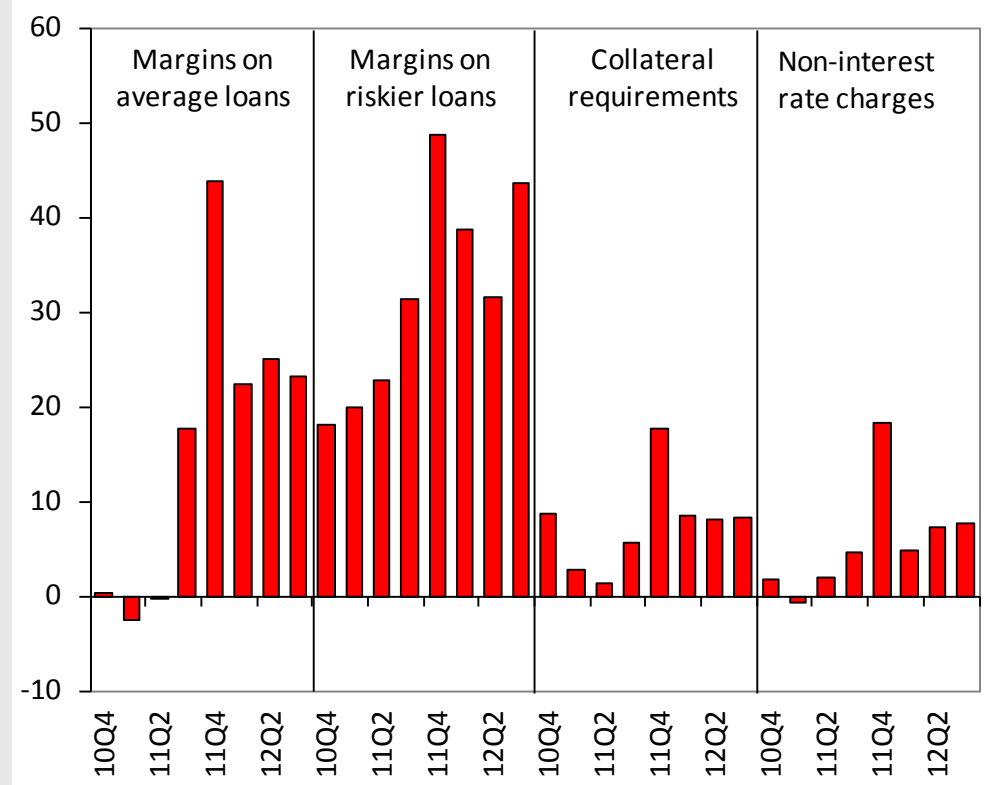

Note: See the notes to Chart 1.

The increase in the net tightening of credit standards on loans to enterprises in the third quarter of 2012 was also reflected in a further widening of margins on riskier loans, whereas changes in the remaining terms and conditions were limited. Specifically, the widening of margins on average loans changed little compared with the second quarter of 
2012 (23\%, after 25\% in the second quarter of 2012). By contrast, the widening of margins on riskier loans increased strongly, to $44 \%$ in the third quarter of 2012, from 32\% in the previous quarter. Such price developments seem to reflect a more pronounced degree of risk-related price differentiation by banks across borrowers. Regarding nonprice components, the net percentage of banks reporting an increase in collateral requirements remained unchanged relative to the second quarter of 2012 (at 8\%).

Looking ahead to the fourth quarter of 2012, on balance, euro area banks expect a similar degree of net tightening in credit standards for loans to enterprises (13\%) as in the third quarter of 2012 (see Chart 1). The net tightening of credit standards is expected to decline in the case of loans to SMEs (7\%), large firms (10\%) and short-term loans (6\%), while banks expect it to remain broadly unchanged for long-term loans (15\%).

\section{I.2 SOMEWHAT MORE PRONOUNCED NET DECLINE IN THE DEMAND FOR LOANS TO NON-FINANCIAL CORPORATIONS}

Euro area banks reported a more pronounced net decline in the demand for loans to enterprises in the third quarter of 2012 (-27\%, after -25\% in the second quarter of 2012; see Chart 3). For the fourth quarter of 2012, euro area banks continue to expect a net decline in demand for loans to enterprises, but considerably less negative than in the third quarter of 2012 (-10\% on balance). The main drivers of the more pronounced net decline in demand for loans to enterprises were mergers and acquisitions $(-17 \%$, after $-13 \%$ in the second quarter of 2012) and inventories and working capital (-11\%, after $-4 \%$ in the second quarter of 2012). The use of other external sources of finance also contributed to the more pronounced net decline in demand for loans. On balance, euro area banks reported a stronger contribution to the net decline in demand stemming from issuance of debt securities $(-5 \%$, after $0 \%$ in the second quarter of 2012), issuance of equity $(-2 \%$, after $2 \%$ in the second quarter of 2012) and loans from non-banks (-2\%, after $-1 \%$ in the second quarter of 2012). By contrast, the negative impact on the financing needs of firms from fixed investment and from internal sources of financing contributed somewhat less to the decline in net demand for loans (-33\%, after -36\% in the second quarter of 2012 for fixed investment; and $-9 \%$, after $-12 \%$ in the second quarter of 2012 for internal sources of financing). 


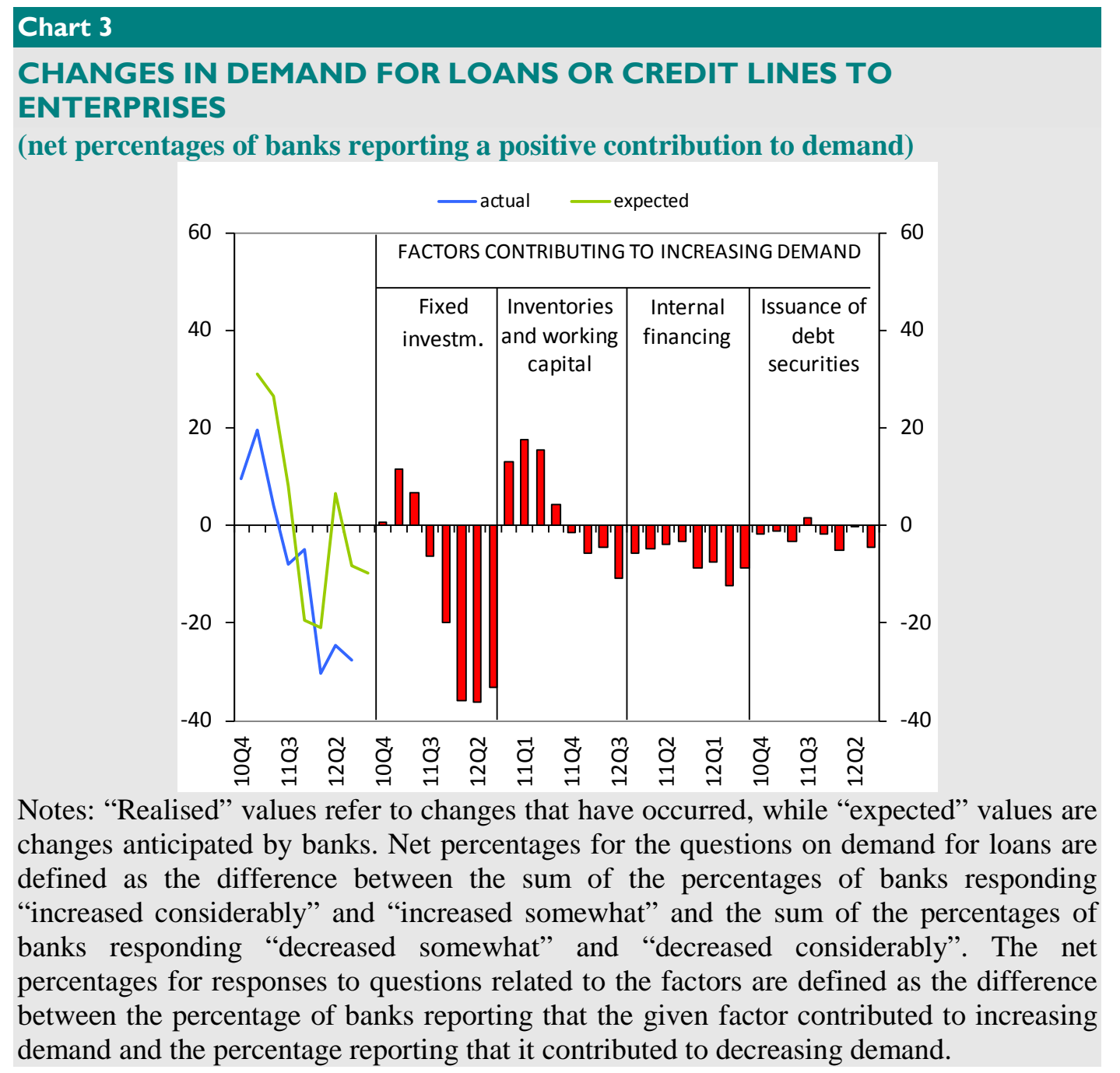

\subsection{HOUSEHOLDS}

\subsection{BROADLY STABLE NET TIGHTENING OF CREDIT STANDARDS ON LOANS TO HOUSEHOLDS FOR HOUSE PURCHASE}

In the third quarter of 2012, euro area banks reported a broadly unchanged net tightening of credit standards on loans to households for house purchase (12\%, from $13 \%$; see Chart 4). The net tightening of credit standards on loans to households for house purchase was higher than expected by the reporting banks at the time of the previous survey round (5\%). As with loans to enterprises, pressures from cost of funds and balance sheet constraints also eased in the case of credit standards on housing loans (to $9 \%$ in net terms, from $14 \%$ in the second quarter of 2012). At the same time, the impact on credit standards of the general economic outlook (10\%, after $11 \%$ in the second quarter of 2012) and of housing 
market prospects (8\%, after $9 \%$ in the second quarter of 2012) remained broadly unchanged in the third quarter of 2012. Competitive pressures were reported to remain neutral.

\section{Chart 4}

CHANGES IN CREDIT STANDARDS APPLIED TO THE APPROVAL OF LOANS TO HOUSEHOLDS FOR HOUSE PURCHASE

(net percentages of banks reporting a contribution to tightening credit standards)

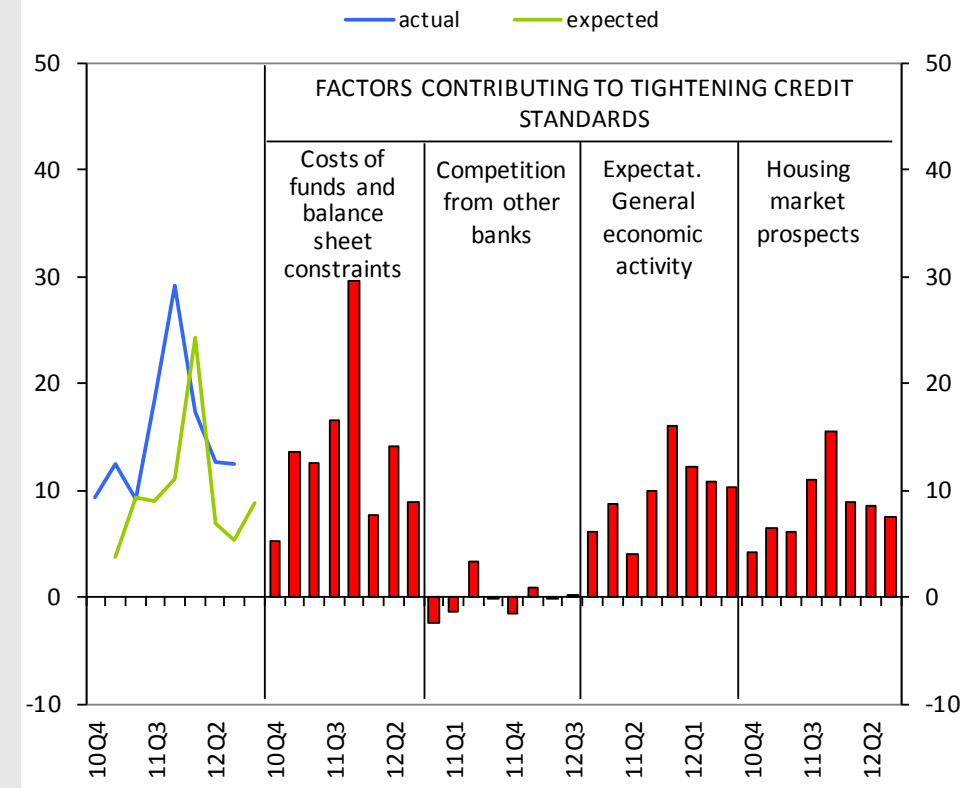

Note: See the notes to Chart 1.

Terms and conditions on housing loans exhibited a mixed behaviour across price and nonprice categories in the third quarter of 2012. The net percentage of banks reporting a widening of margins on average housing loans remained broadly unchanged (14\% in net terms, after $15 \%$ in the second quarter of 2012), while it declined slightly in the case of margins on riskier housing loans (19\% in net terms, down from $21 \%$ in the second quarter of 2012). The small decline in the net percentage of banks reporting a widening of margins on riskier housing loans contrasts notably with the strong increase in the case of loans to enterprises. Responses regarding non-price terms and conditions point to a slight tightening in the case of loan-to-value ratios (8\%, up from $6 \%$ in the second quarter of 2012) and non-interest rate charges (3\%, up from $1 \%$ in the second quarter of 2012), and some moderation for the maturity of loans ( $3 \%$, down from $5 \%$ in the second quarter of 2012). 
Looking ahead, 9\% of euro area banks - in net terms - expect a further tightening of credit standards on loans to households for house purchase in the fourth quarter of 2012.

\subsubsection{A SOMEWHAT STRONGER NET DECLINE IN DEMAND FOR HOUSING LOANS}

Similar to corporate loan demand, euro area banks reported on balance a further contraction in the demand for housing loans in the third quarter of 2012, at a somewhat faster pace than in the previous survey round (-25\%, compared with $-21 \%$ in the second quarter of 2012; see Chart 5). Both housing market prospects $(-14 \%$, after $-25 \%$ in the second quarter of 2012) and consumer confidence (-23\%, after $-27 \%$ in the second quarter of 2012) contributed to the considerable net decline in demand for housing loans, although to a lesser extent than in the previous survey round. By contrast, the use of households' savings as an alternative source of finance contributed somewhat more strongly to the net decline in demand for housing loans (-9\%, after $-8 \%$ in the second quarter of 2012).

Looking ahead, $10 \%$ of euro area banks - in net terms - expect demand for loans for house purchase to decline further in the fourth quarter of 2012, hinting at a lower net decline in demand than in the current quarter. 


\section{Chart 5}

\section{CHANGES IN DEMAND FOR LOANS TO HOUSEHOLDS FOR HOUSE}

PURCHASE

(net percentages of banks reporting a positive contribution to demand)

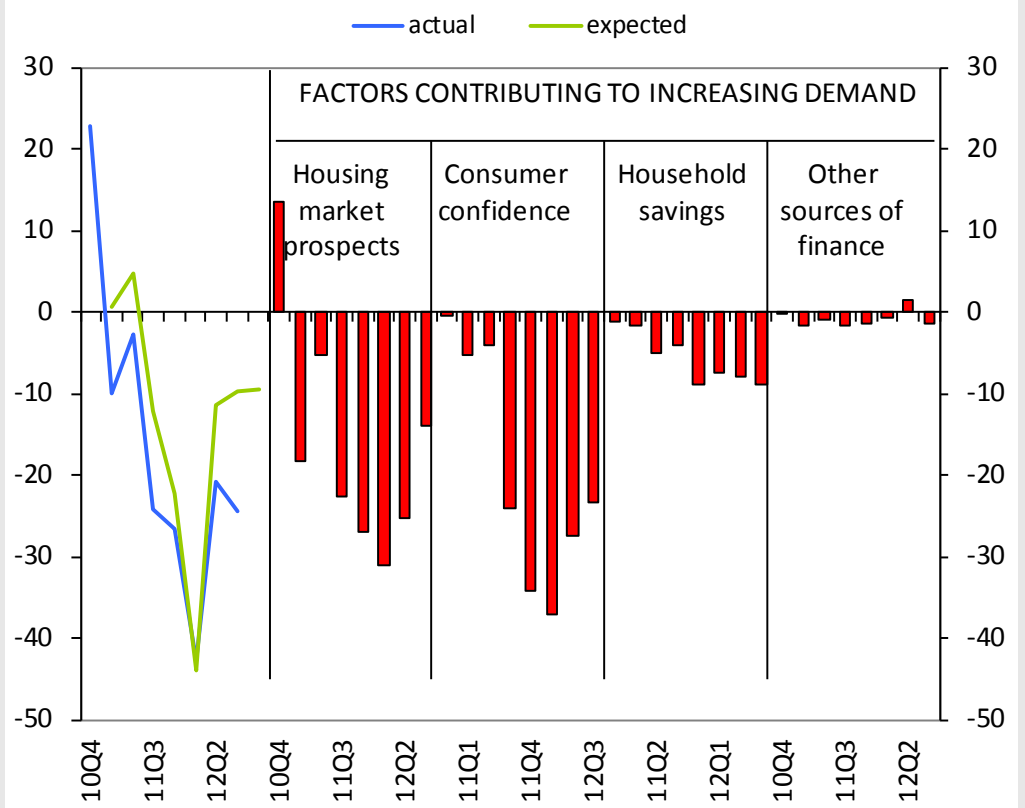

Note: See the notes to Chart 3.

\subsubsection{DECLINE IN THE NET TIGHTENING OF CREDIT STANDARDS FOR CONSUMER LOANS}

The net tightening of credit standards for consumer credit reported by euro area banks declined slightly in the third quarter of 2012, to 3\%, from 7\% in the second quarter of 2012 (see Chart 6). Similar to corporate and housing loans, pressures emerging from cost of funds and balance sheet constraints on credit standards eased in the third quarter of 2012 (to 1\%, from 8\% in the second quarter of 2012). At the same time, in the third quarter of 2012 banks assessed the impact from the risk environment to be unchanged in the case of expectations regarding the economic outlook (at 8\%), while the assessed impact declined somewhat in the case of the creditworthiness of loan applicants (to 4\%, from $7 \%$ in the second quarter of 2012).

With regard to the terms and conditions on consumer credit, banks reported on balance a slight increase in the widening of margins on both riskier consumer loans (to 14\%, from $13 \%$ in the second quarter of 2012) and average consumer loans (to $13 \%$, from $11 \%$ in the second quarter of 2012). In addition, non-price terms and conditions on consumer credit remained broadly neutral. 
Looking ahead, a small proportion of euro area banks - $2 \%$ in net terms - expect a further tightening of credit standards on consumer credit in the fourth quarter of 2012.

\section{Chart 6}

CHANGES IN CREDIT STANDARDS APPLIED TO THE APPROVAL OF CONSUMER CREDIT AND OTHER LENDING TO HOUSEHOLDS (net percentages of banks contributing to tightening credit standards)

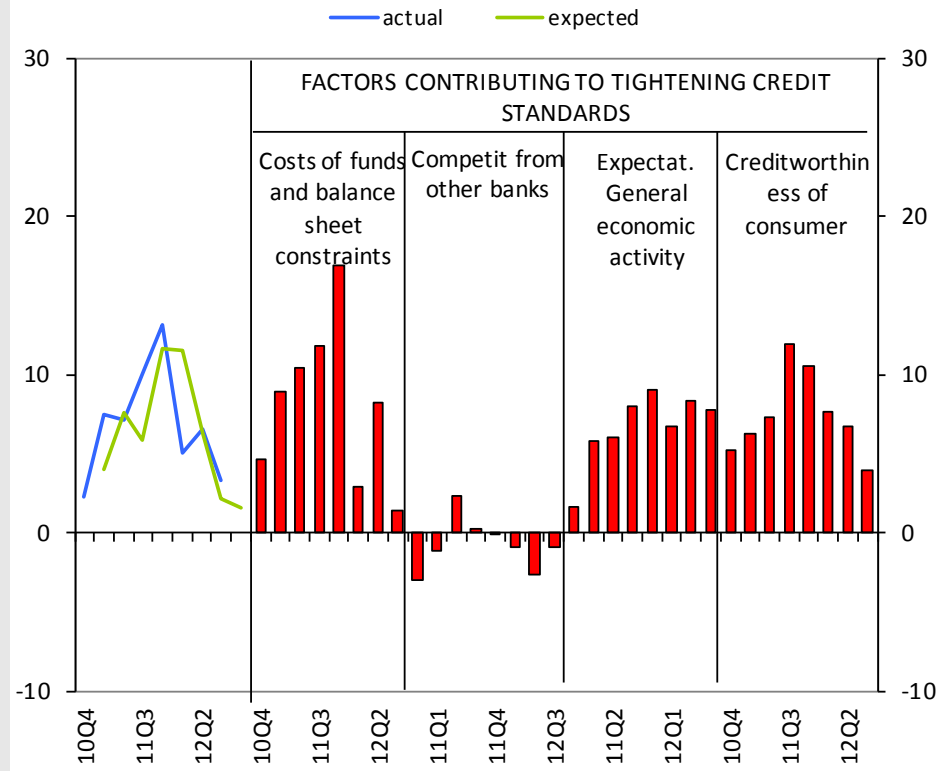

Note: See the notes to Chart 1.

\subsubsection{MORE MODERATE NET DECLINE IN DEMAND FOR CONSUMER CREDIT}

Net demand for consumer credit continued to decline strongly in the third quarter of 2012, at $-22 \%$ according to euro area banks, compared with $-27 \%$ in the previous survey round. According to euro area banks, the protracted decline was driven by less household spending on durable goods (-18\%, compared with $-28 \%$ in the second quarter of 2012) and a decrease in consumer confidence (-22\%, compared with $-26 \%$ in the second quarter of 2012).

Looking ahead, for the fourth quarter of 2012, euro area banks expect a substantial deceleration in the net decline of demand for consumer credit (-12\% in net terms). 


\section{AD HOC QUESTIONS}

\section{I.I IMPROVEMENT IN ACCESSING RETAIL AND WHOLESALE FUNDING IN THE THIRD QUARTER OF 2012}

As in previous surveys, the October 2012 survey questionnaire included a question which aimed at assessing the extent to which financial market tensions affected banks' credit standards for loans and credit lines to enterprises and households and the extent to which they were expected to affect them in the next three months. Since the fourth quarter of 2011, the question has also assessed access to retail funding. ${ }^{3}$

In the third quarter of 2012, euro area banks reported an improvement in their access to retail and wholesale funding across most funding categories (see Chart 7). In particular, euro area banks reported a net easing in banks' access to retail funding, money markets and debt securities. In the case of securitisation, banks reported a strong moderation in the net deterioration of market access. The overall improvement in banks' access to retail and wholesale markets was stronger than expected at the time of the previous survey round. Looking ahead, for the fourth quarter of 2012, banks expect a net easing in market access in the case of retail funding, money markets and debt securities, whereas for securitisation they expect a further decline in the net deterioration of market access.

${ }^{3}$ The results shown are calculated as a percentage of the number of banks which did not reply "not applicable". 


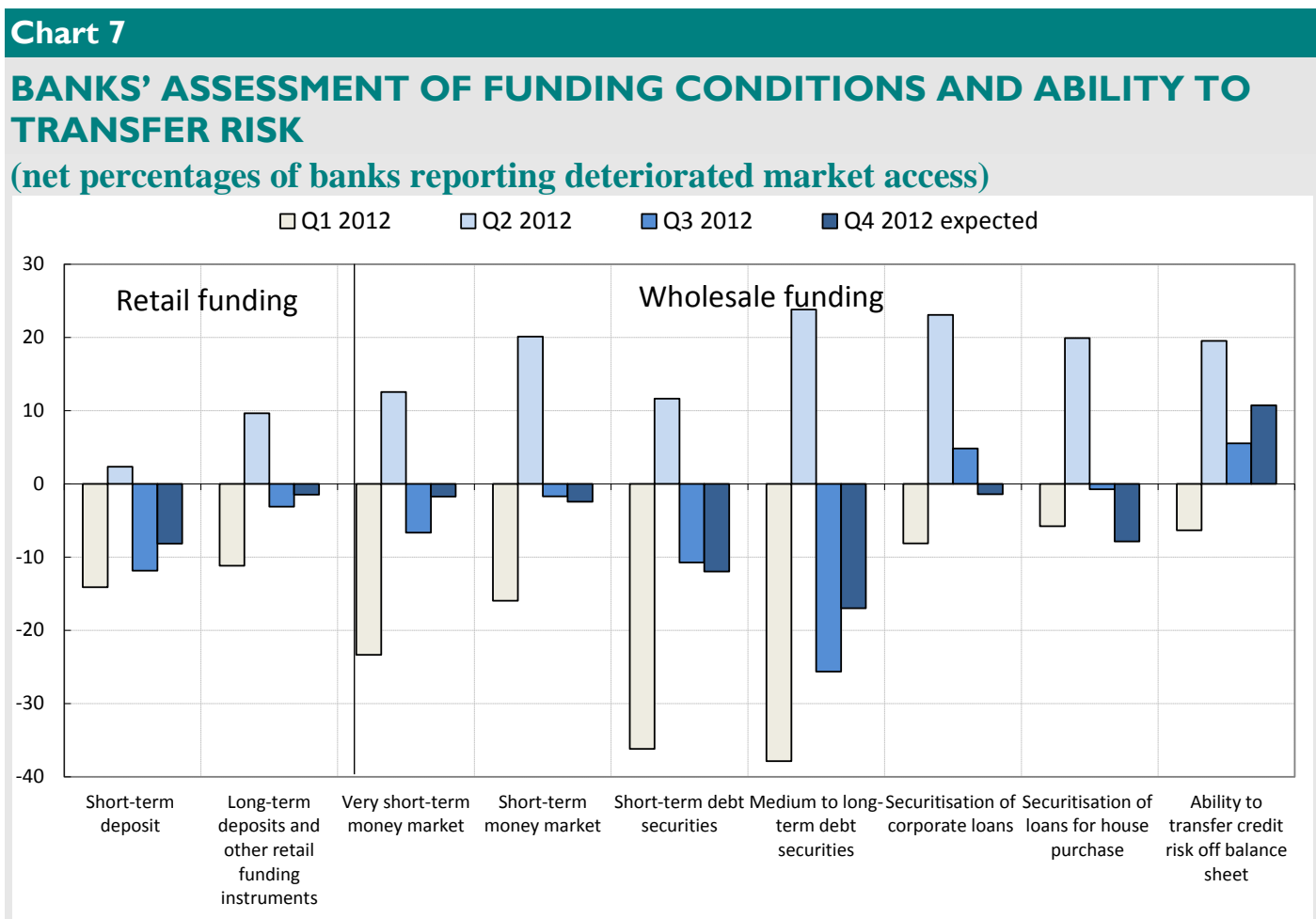

Note: The net percentages are defined as the difference between the sum of the percentages for "deteriorated considerably" and "deteriorated somewhat" and the sum of the percentages for "eased somewhat" and "eased considerably".

\section{I.2 MODERATION IN THE IMPACT OF SOVEREIGN DEBT TENSIONS ON BANKS' FUNDING CONDITIONS AND CREDIT STANDARDS}

As in the previous survey round, the October 2012 survey questionnaire included a question which addressed the specific impact of the sovereign debt crisis on banks' funding conditions and lending policies over the past three months. In principle, bank funding conditions can be primarily affected through two direct channels. First, direct exposure to sovereign debt may weaken banks' balance sheets, increase their riskiness as counterparties and, in turn, make funding more costly and more difficult to obtain. Second, higher sovereign debt risk reduces the value of sovereign collateral that banks can use to raise wholesale funding. Beyond this, other effects may relate sovereign market tensions to bank funding conditions. In particular, the weaker financial positions of governments have lowered the funding benefits that banks derive from implicit or explicit government guarantees. Financial contagion from sovereign to sovereign or from sovereign to banks may also be at play. 
As a likely consequence of the improvement in financial market sentiment, replies to the October survey indicate a considerable moderation in the impact of sovereign debt tensions on banks' funding conditions for all channels (see Chart 8). On balance, only 7\% of the euro area banks attributed a deterioration of funding conditions to the sovereign debt crisis through their direct exposure to sovereign debt, down from 18\% in the previous quarter. In addition, on balance $10 \%$ of the euro area banks reported that the decline in the value of sovereign collateral led to a deterioration in their funding conditions in the third quarter of 2012, after a strong tightening impact on funding conditions in the second quarter of 2012 (24\%). "Other effects”, which may include financial contagion effects, also exhibited a moderation in the impact of sovereign tensions on banks' funding conditions (on balance 15\%, down from 24\% in the second quarter of 2012). These results suggest that the negative impact of the sovereign debt crisis on banks' funding conditions diminished substantially in the course of the third quarter of 2012.

Compared with the previous quarter, the impact of the sovereign debt crisis on banks' credit standards also diminished somewhat at the euro area level. This development is broadly in line with the decline in the impact of the cost of funds and balance sheet constraints on banks' credit standards for loans to enterprises and households. 


\section{Chart 8}

\section{IMPACT OF THE SOVEREIGN DEBT CRISIS ON BANKS' FUNDING CONDITIONS AND CREDIT STANDARDS}

(net percentages of banks reporting an impact on funding conditions or on the tightening of credit standards)

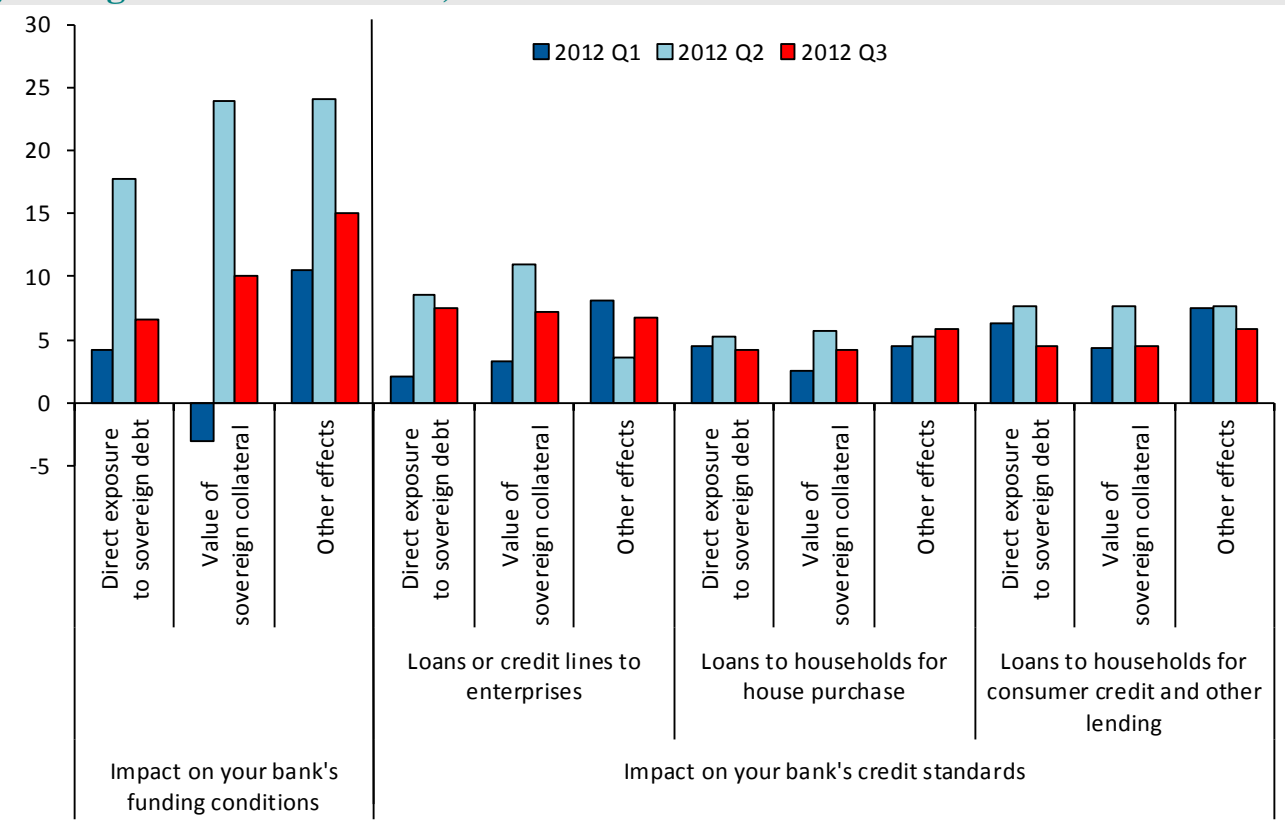

Note: The net percentages are defined as the difference between the sum of the percentages for "contributed to a deterioration of funding conditions/tightening of credit standards considerably" and "somewhat" and the sum of the percentages for "contributed to an easing of funding conditions/easing of credit standards somewhat" and "considerably". 


\section{ANNEX I: RESULTS FOR THE INDIVIDUAL QUESTIONS}

\section{LOANS OR CREDIT LINES TO ENTERPRISES}

1. Over the past three months, how have your bank's credit standards as applied to the approval of loans or credit lines to enterprises changed?

\begin{tabular}{|c|c|c|c|c|c|c|c|c|c|c|}
\hline & \multicolumn{2}{|c|}{ Overall } & \multicolumn{2}{|c|}{$\begin{array}{c}\text { Loans to small } \\
\text { and medium- } \\
\text { sized enterprises }\end{array}$} & \multicolumn{2}{|c|}{$\begin{array}{l}\text { Loans to large } \\
\text { enterprises }\end{array}$} & \multicolumn{2}{|c|}{ Short-term loans } & \multicolumn{2}{|c|}{ Long-term Iolans } \\
\hline & Jul & Oct & Jul & Oct & Jul & Oct & Jul & Oct & Jul & dct \\
\hline Tightened considerably & $1 \%$ & $0 \%$ & $1 \%$ & $1 \%$ & $3 \%$ & $0 \%$ & $1 \%$ & $0 \%$ & $1 \%$ & $0 \%$ \\
\hline Tightened somewhat & $10 \%$ & $15 \%$ & $7 \%$ & $10 \%$ & $14 \%$ & $17 \%$ & $8 \%$ & $11 \%$ & $11 \%$ & $15 \%$ \\
\hline Remained basically unchanged & $89 \%$ & $84 \%$ & $91 \%$ & $87 \%$ & $82 \%$ & $83 \%$ & $91 \%$ & $88 \%$ & $87 \%$ & $84 \%$ \\
\hline Eased somewhat & $1 \%$ & $1 \%$ & $2 \%$ & $1 \%$ & $1 \%$ & $0 \%$ & $1 \%$ & $1 \%$ & $1 \%$ & $1 \%$ \\
\hline Eased considerably & $0 \%$ & $0 \%$ & $0 \%$ & $0 \%$ & $0 \%$ & $0 \%$ & $0 \%$ & $0 \%$ & $0 \%$ & $0 \%$ \\
\hline Total & $100 \%$ & $100 \%$ & $100 \%$ & $100 \%$ & $100 \%$ & $100 \%$ & $100 \%$ & $100 \%$ & $100 \%$ & $10 p \%$ \\
\hline Net percentage & $10 \%$ & $15 \%$ & $6 \%$ & $11 \%$ & $16 \%$ & $17 \%$ & $8 \%$ & $11 \%$ & $11 \%$ & $14 \%$ \\
\hline Diffusion index & $5 \%$ & $7 \%$ & $3 \%$ & $6 \%$ & $10 \%$ & $9 \%$ & $4 \%$ & $5 \%$ & $6 \%$ & $7 \%$ \\
\hline Mean & 2.90 & 2.85 & 2.93 & 2.88 & 2.81 & 2.83 & 2.92 & 2.89 & 2.87 & 2.36 \\
\hline Standard deviation & 0.37 & 0.40 & 0.34 & 0.41 & 0.52 & 0.40 & 0.34 & 0.35 & 0.41 & 0.40 \\
\hline Number of banks responding & 124 & 125 & 120 & 122 & 119 & 119 & 124 & 125 & 123 & 124 \\
\hline
\end{tabular}

Notes: Net percentage is defined as the difference between the sum of the percentages for "tightened considerably" and "tightened somewhat" and the sum of the percentages for "eased somewhat" and "eased considerably". The diffusion index is defined as the net percentage weighted according to the intensity of the response, giving lenders who have answered "considerably" a weight twice as high (score of 1) as lenders having answered "somewhat" (score of 0.5).

The mean and standard deviation are calculated by attributing the values 1 to 5 starting with the first possible answer and consequently for the other answers. These values are then multiplied with the corresponding (weighted) percentages. 


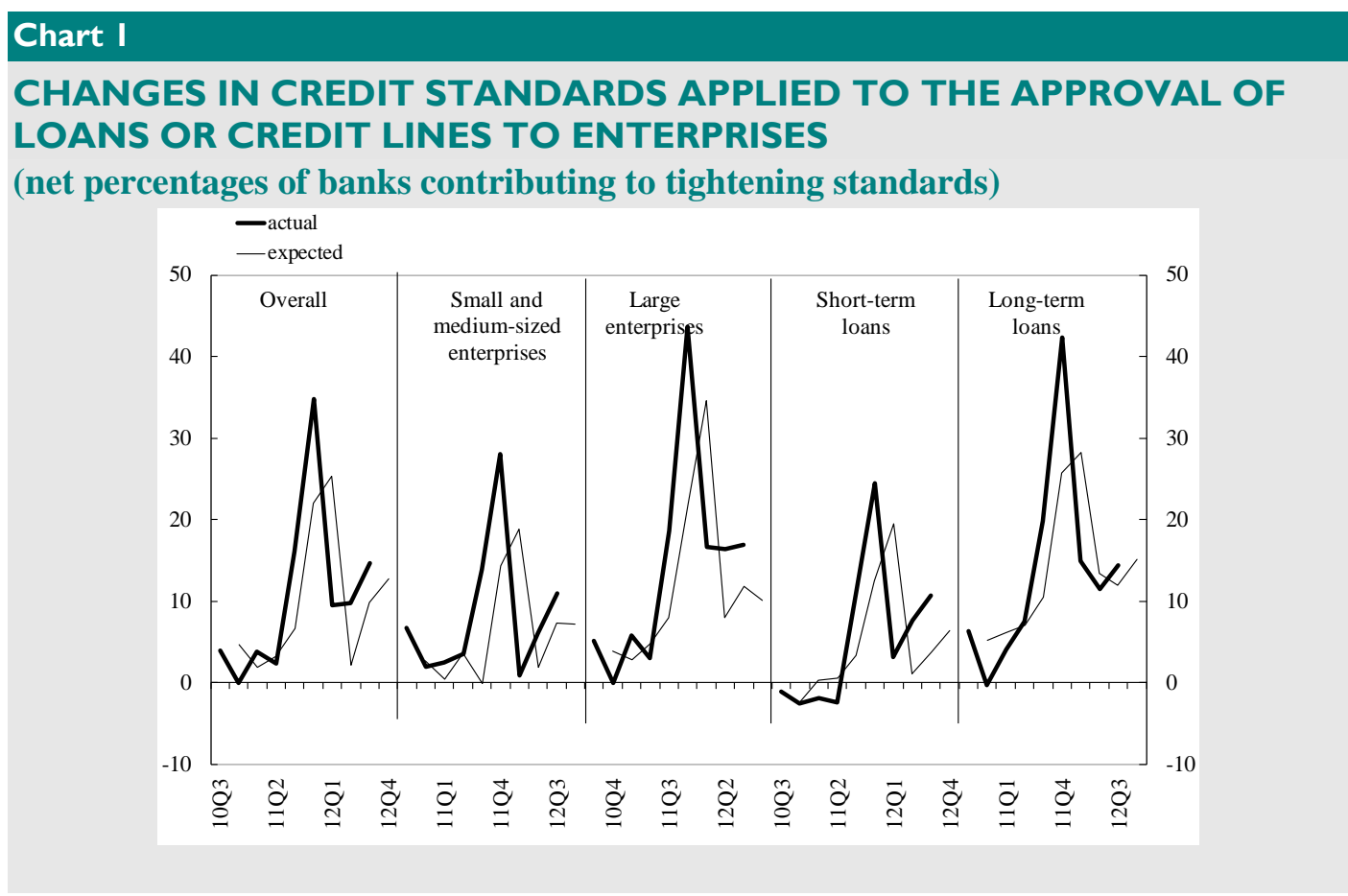

2. Over the past three months, how have the following factors affected your bank's credit standards as applied to the approval of loans or credit lines to enterprises?

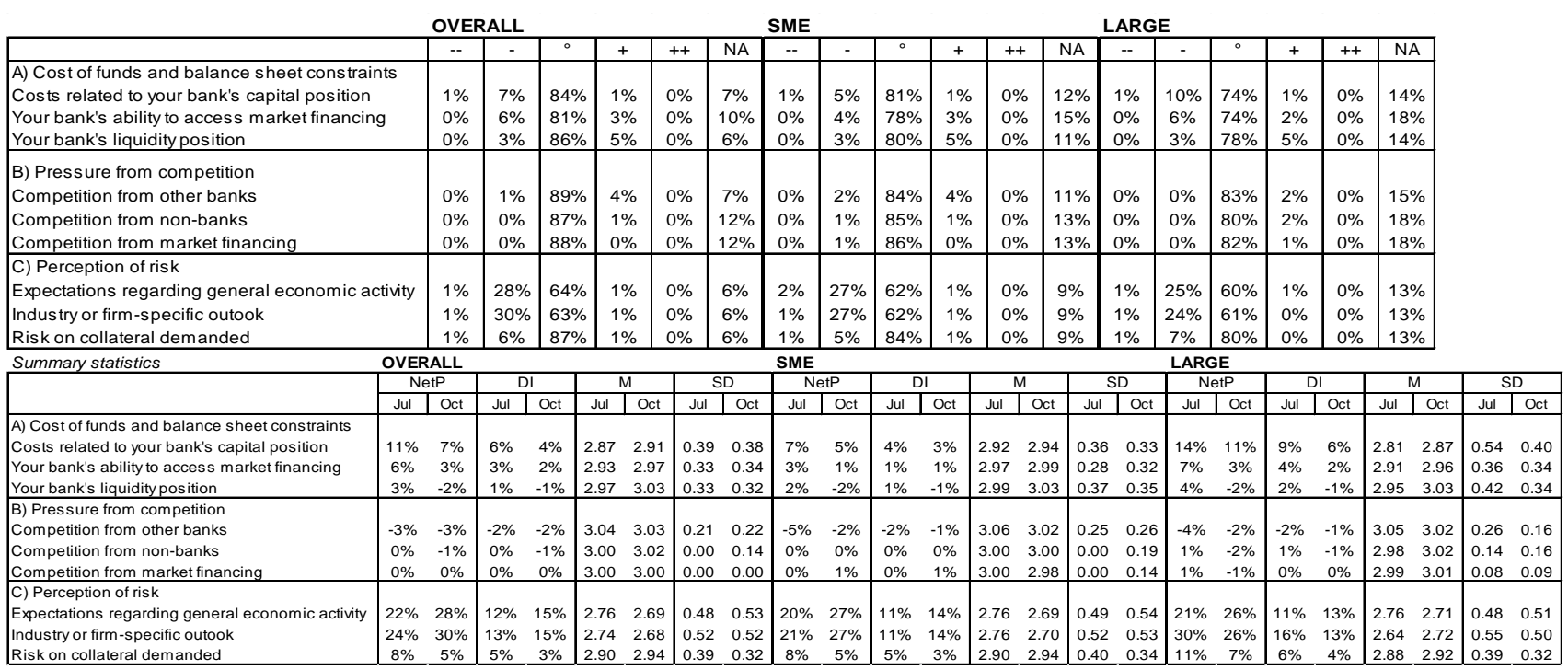

NA = Not available; NetP = Net percentage; $\mathrm{DI}=$ Diffusion index; $\mathrm{M}=$ Mean; $\mathrm{SD}=$ Standard deviation

Notes: Column "Net percentage" is defined as the difference between the sum of "- -“ (contributed considerably to tightening) and "_- (contributed somewhat to tightening) and the sum of "+" (contributed somewhat to easing) and "+ +" (contributed considerably to easing).” " means contributed to basically unchanged. The diffusion index is defined as the net percentage weighted according to the intensity of the response, giving lenders who have answered "considerably" a weight twice as high (score of 1) as lenders having answered "somewhat" (score of 0.5). 


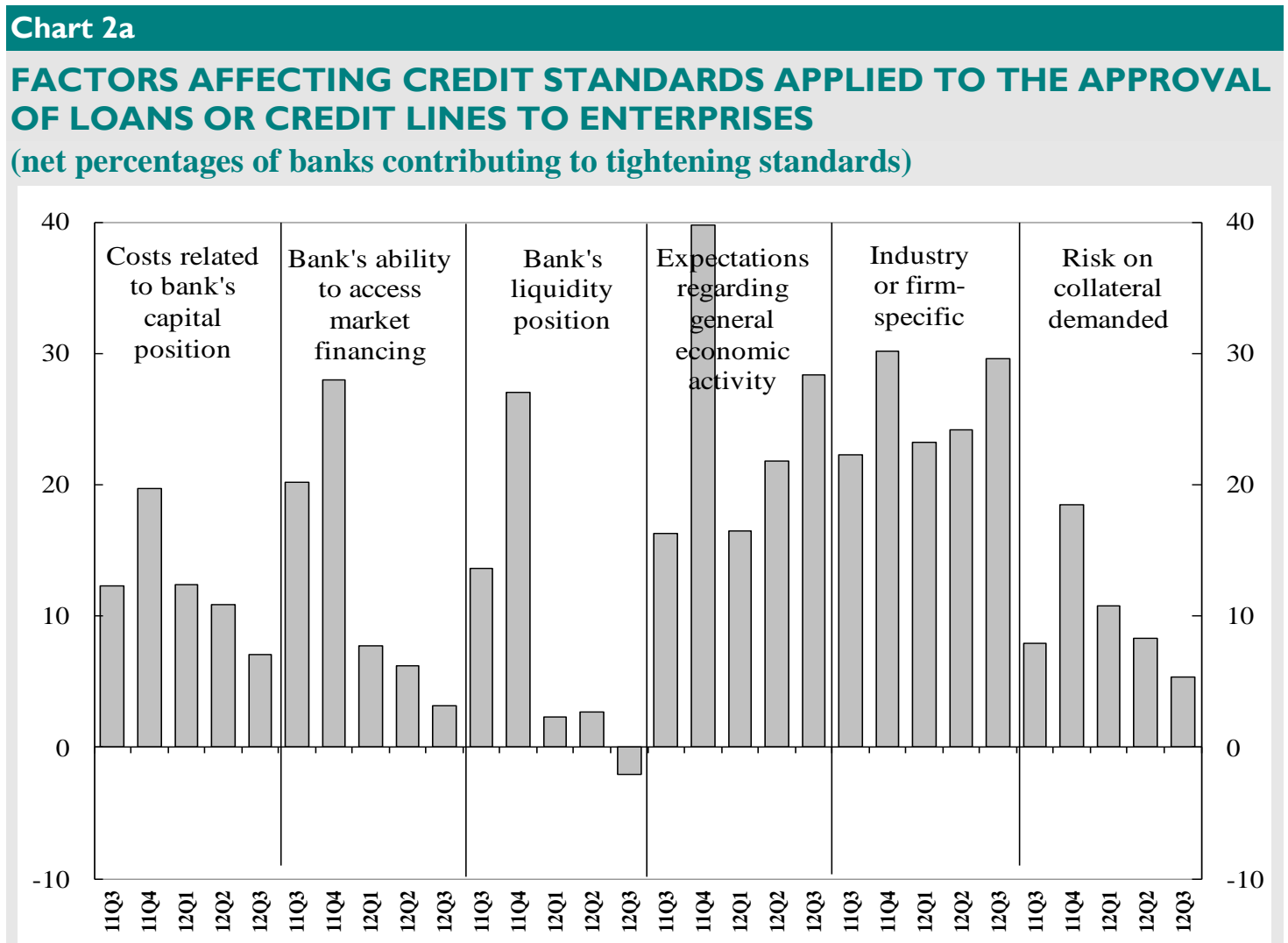

\section{Chart 2b}

FACTORS AFFECTING CREDIT STANDARDS APPLIED TO THE APPROVAL OF LOANS OR CREDIT LINES TO ENTERPRISES

(net percentages of banks contributing to tightening standards)

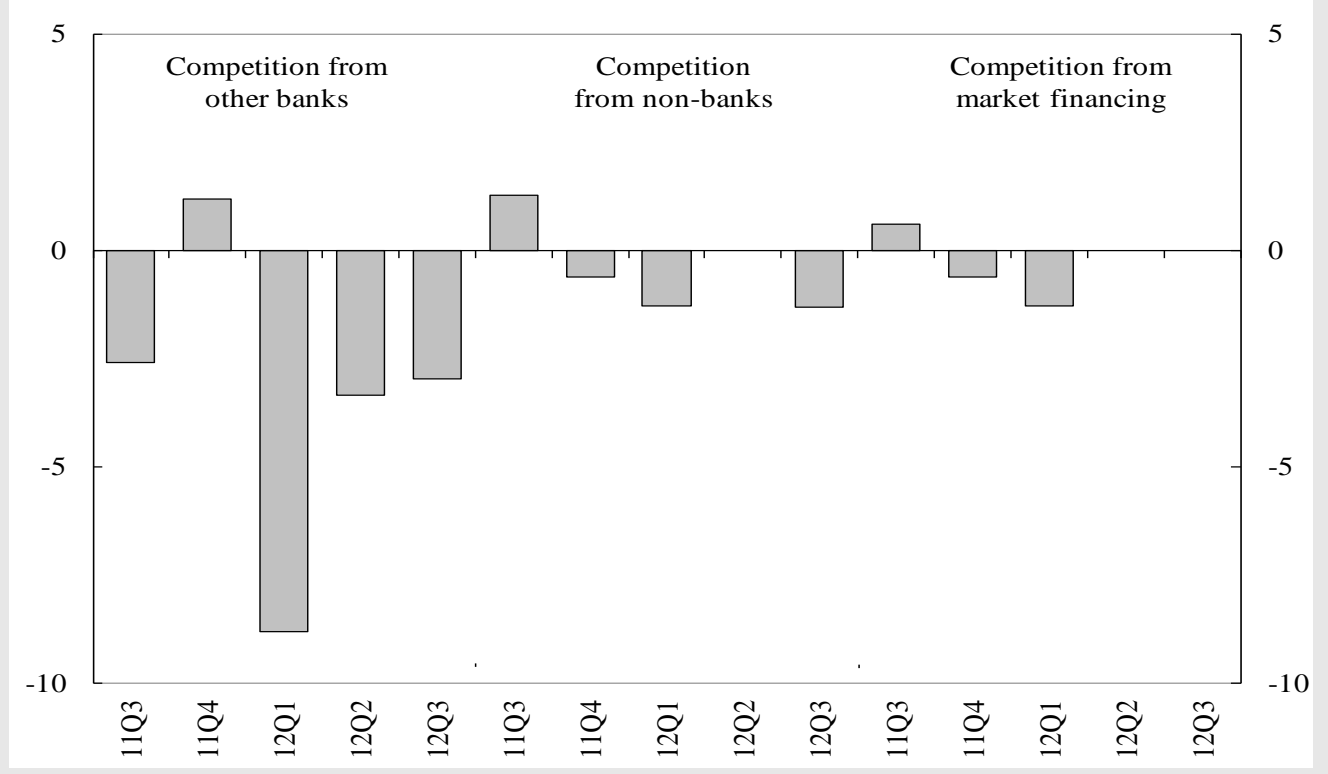


3. Over the past three months, how have your bank's conditions and terms for approving loans or credit lines to enterprises changed?

\begin{tabular}{|c|c|c|c|c|c|c|c|c|c|c|c|c|c|c|c|c|c|c|}
\hline & \multicolumn{6}{|c|}{ OVERALL } & \multicolumn{6}{|c|}{ SME } & \multicolumn{6}{|c|}{ LARGE } \\
\hline & -- & - & $\circ$ & + & ++ & NA & -- & - & $\circ$ & + & ++ & NA & -- & - & o & + & +++ & NA \\
\hline $\begin{array}{l}\text { A) Price } \\
\text { Your bank's margin on average loans }\end{array}$ & $1 \%$ & $25 \%$ & $67 \%$ & $2 \%$ & $0 \%$ & $6 \%$ & $1 \%$ & $21 \%$ & $66 \%$ & $3 \%$ & $0 \%$ & $9 \%$ & $2 \%$ & $23 \%$ & $60 \%$ & $3 \%$ & $0 \%$ & $13 \%$ \\
\hline Your bank's margin on riskier loans & $1 \%$ & $44 \%$ & $50 \%$ & $1 \%$ & $0 \%$ & $6 \%$ & $1 \%$ & $36 \%$ & $53 \%$ & $1 \%$ & $0 \%$ & $9 \%$ & $5 \%$ & $35 \%$ & $46 \%$ & $1 \%$ & $0 \%$ & $13 \%$ \\
\hline $\begin{array}{l}\text { B) Other conditions and terms } \\
\text { Non-interest rate charges }\end{array}$ & $0 \%$ & $8 \%$ & $86 \%$ & $1 \%$ & $0 \%$ & $6 \%$ & $0 \%$ & $7 \%$ & $84 \%$ & $0 \%$ & $0 \%$ & $9 \%$ & $0 \%$ & $9 \%$ & $77 \%$ & $1 \%$ & $0 \%$ & $13 \%$ \\
\hline Size of the loan or credit line & $1 \%$ & $8 \%$ & $86 \%$ & $1 \%$ & $0 \%$ & $6 \%$ & $1 \%$ & $5 \%$ & $84 \%$ & $1 \%$ & $0 \%$ & $9 \%$ & $1 \%$ & $11 \%$ & $75 \%$ & $0 \%$ & $0 \%$ & $13 \%$ \\
\hline Collateral requirements & $1 \%$ & $9 \%$ & $84 \%$ & $1 \%$ & $0 \%$ & $6 \%$ & $1 \%$ & $10 \%$ & $80 \%$ & $0 \%$ & $0 \%$ & $10 \%$ & $1 \%$ & $11 \%$ & $74 \%$ & $1 \%$ & $0 \%$ & $14 \%$ \\
\hline Loan covenants & $1 \%$ & $6 \%$ & $87 \%$ & $1 \%$ & $0 \%$ & $6 \%$ & $1 \%$ & $5 \%$ & $84 \%$ & $1 \%$ & $0 \%$ & $10 \%$ & $1 \%$ & $8 \%$ & $79 \%$ & $0 \%$ & $0 \%$ & $14 \%$ \\
\hline Maturity & $1 \%$ & $13 \%$ & $80 \%$ & $1 \%$ & $0 \%$ & $6 \%$ & $1 \%$ & $11 \%$ & $78 \%$ & $1 \%$ & $0 \%$ & $9 \%$ & $1 \%$ & $15 \%$ & $71 \%$ & $0 \%$ & $0 \%$ & $13 \%$ \\
\hline
\end{tabular}

\begin{tabular}{|c|c|c|c|c|c|c|c|c|c|c|c|c|c|c|c|c|c|c|c|c|c|c|c|c|}
\hline \multirow{3}{*}{ Summary statistics } & \multirow{2}{*}{\multicolumn{2}{|c|}{$\begin{array}{l}\text { OVERALL } \\
\begin{array}{|c|}\text { NetP } \\
\end{array}\end{array}$}} & \multirow{2}{*}{\multicolumn{2}{|c|}{$\mathrm{DI}$}} & \multirow{2}{*}{\multicolumn{2}{|c|}{ M }} & \multicolumn{4}{|c|}{ SME } & \multirow{2}{*}{\multicolumn{2}{|c|}{ DI }} & \multirow{2}{*}{\multicolumn{2}{|c|}{ M }} & \multirow{2}{*}{\multicolumn{2}{|c|}{ SD }} & \multirow{2}{*}{\multicolumn{2}{|c|}{$\begin{array}{l}\text { LARGE } \\
\text { NetP } \\
\end{array}$}} & \multirow{2}{*}{\multicolumn{2}{|c|}{$\mathrm{DI}$}} & & & & \\
\hline & & & & & & & S & D & $\mathrm{Ne}$ & & & & & & & & & & & & \multicolumn{2}{|c|}{$M$} & \multicolumn{2}{|c|}{$\mathrm{SD}$} \\
\hline & Jul & \begin{tabular}{|l|} 
Oct \\
\end{tabular} & Jul & Oct & Jul & Oct & Jul & Oct & Jul & \begin{tabular}{|l|l|} 
Oct \\
\end{tabular} & Jul & Oct & Jul & Oct & Jul & Oct & Jul & \begin{tabular}{|l|l|} 
Oct \\
\end{tabular} & \begin{tabular}{l|l} 
Jul & \\
\end{tabular} & Oct & Jul & Oct & Jul & Oct \\
\hline $\begin{array}{l}\text { A) Price } \\
\text { Your bank }\end{array}$ & $\%$ & $23 \%$ & $13 \%$ & $12 \%$ & 74 & 2.75 & 0.50 & 0.52 & $22 \%$ & $19 \%$ & $11 \%$ & $10 \%$ & 2.76 & 2.80 & 49 & 0.51 & $5 \%$ & $22 \%$ & $3 \%$ & $12 \%$ & .70 & 2.74 & 0.58 & \\
\hline Your ba & $32 \%$ & $44 \%$ & $17 \%$ & $22 \%$ & 2.66 & 2.54 & 0.58 & 0.55 & $30 \%$ & $36 \%$ & $16 \%$ & $19 \%$ & 2.65 & 2.61 & 0.59 & 0.55 & $33 \%$ & $39 \%$ & $18 \%$ & $22 \%$ & 2.59 & 2.52 & 0.63 & 0.64 \\
\hline & 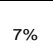 & $8 \%$ & $4 \%$ & & & 2.92 & 8 & 0.31 & & $7 \%$ & $3 \%$ & $4 \%$ & 4 & 2.93 & 25 & 0.27 & $\%$ & $\%$ & $\%$ & $4 \%$ & 89 & & & \\
\hline Size of the lo & $7 \%$ & $7 \%$ & $4 \%$ & $4 \%$ & 2.92 & 2.92 & 0.31 & 0.34 & $3 \%$ & $5 \%$ & $2 \%$ & $3 \%$ & 2.96 & 2.95 & 0.24 & 0.31 & $11 \%$ & $12 \%$ & $7 \%$ & $6 \%$ & 85 & 2.87 & 0.44 & 0.38 \\
\hline & $8 \%$ & $8 \%$ & $5 \%$ & $4 \%$ & 2.91 & 2.91 & 0.38 & 0.35 & $9 \%$ & $11 \%$ & $5 \%$ & $6 \%$ & 2.90 & 2.88 & 0.40 & 0.36 & $11 \%$ & $11 \%$ & $6 \%$ & $6 \%$ & 2.87 & 2.87 & 0.39 & 0.42 \\
\hline Loans covenants & $8 \%$ & $5 \%$ & $5 \%$ & $3 \%$ & 2.90 & 2.94 & 0.36 & 0.31 & $6 \%$ & $4 \%$ & $3 \%$ & $2 \%$ & 2.93 & 2.95 & 0.33 & 0.31 & $11 \%$ & $8 \%$ & $6 \%$ & $4 \%$ & 2.86 & 2.91 & 0.40 & 0.33 \\
\hline Maturity & $11 \%$ & $12 \%$ & $6 \%$ & $6 \%$ & 2.88 & 2.87 & 0.36 & 0.41 & $12 \%$ & $11 \%$ & $6 \%$ & $6 \%$ & 2.86 & 2.89 & 0.38 & 0.39 & $13 \%$ & $16 \%$ & $7 \%$ & $9 \%$ & 2.84 & 2.81 & 0.46 & 0.45 \\
\hline
\end{tabular}

NA = Not available; NetP = Net percentage; DI = Diffusion index; $\mathrm{M}$ = Mean; SD = Standard deviation

Notes: Column "Net percentage" is defined as the difference between the sum of "- - " (tightened considerably) and "“" (tightened somewhat) and the sum of "“+ (eased somewhat) and "+ +" (eased considerably). "o, means remained basically unchanged. The diffusion index is defined as the net percentage weighted according to the intensity of the response, giving lenders who have answered "considerably" a weight twice as high (score of 1 ) as lenders having answered "somewhat" (score of 0.5).

\section{Chart 3}

CHANGES IN TERMS AND CONDITIONS FOR APPROVING LOANS OR CREDIT LINES TO ENTERPRISES

(net percentages of banks reporting tightening terms and conditions)

\section{OVERALL}

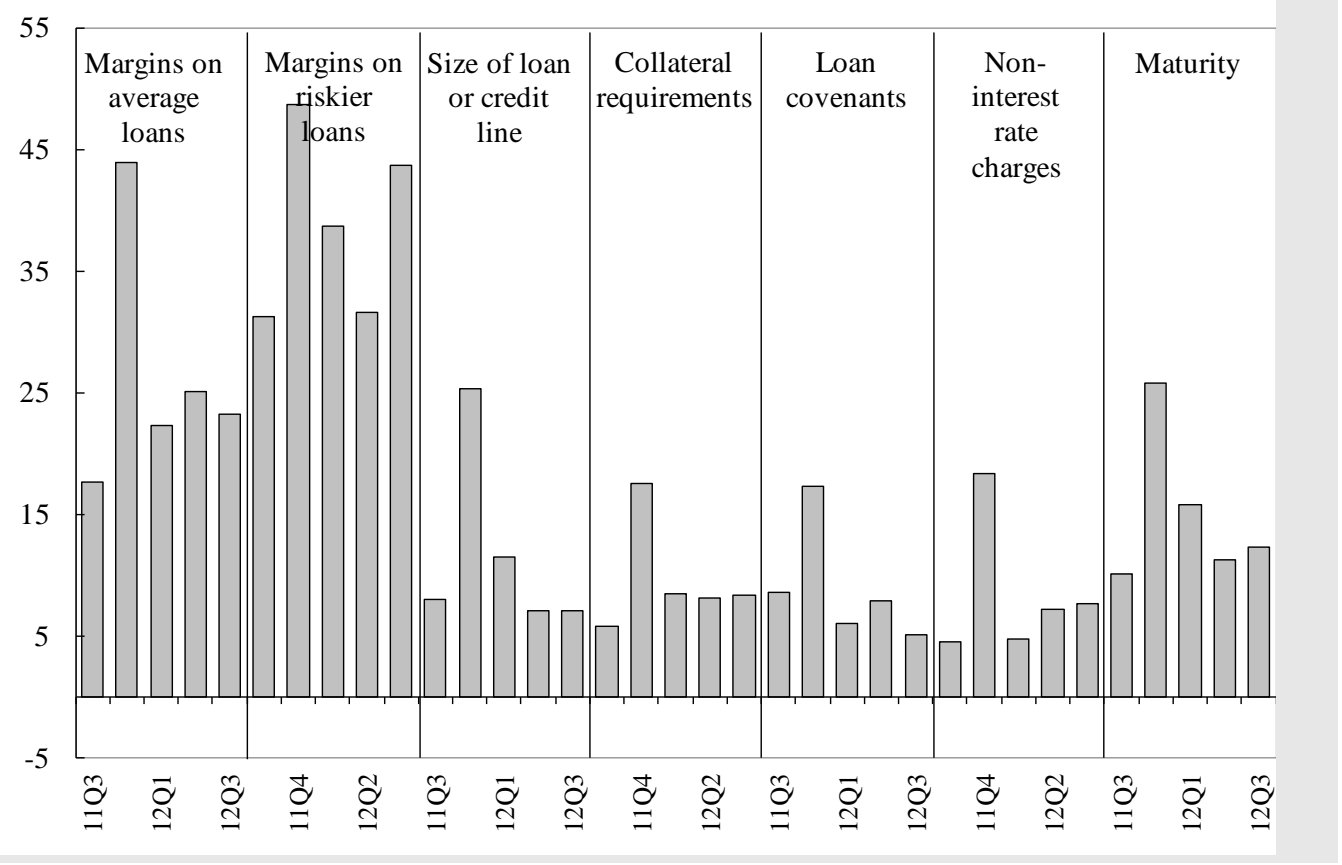


4. Over the past three months, how has the demand for loans or credit lines to enterprises changed at your bank, apart from normal seasonal fluctuations?

\begin{tabular}{|c|c|c|c|c|c|c|c|c|c|c|}
\hline & \multicolumn{2}{|c|}{ Overall } & \multicolumn{2}{|c|}{$\begin{array}{c}\text { Loans to small } \\
\text { and medium-sized } \\
\text { enterprises }\end{array}$} & \multicolumn{2}{|c|}{$\begin{array}{l}\text { Loans to large } \\
\text { enterprises }\end{array}$} & \multicolumn{2}{|c|}{ Short-term loans } & \multicolumn{2}{|c|}{ Long-term loans } \\
\hline & Jul & Oct & Jul & Oct & Jul & Oct & Jul & Oct & Jul & Oct \\
\hline Decreased considerably & $3 \%$ & $1 \%$ & $4 \%$ & $1 \%$ & $5 \%$ & $2 \%$ & $3 \%$ & $1 \%$ & $5 \%$ & $2 \%$ \\
\hline Decreased somewhat & $31 \%$ & $32 \%$ & $25 \%$ & $33 \%$ & $26 \%$ & $28 \%$ & $24 \%$ & $22 \%$ & $28 \%$ & $30 \%$ \\
\hline Remained basically unchanged & $55 \%$ & $62 \%$ & $58 \%$ & $56 \%$ & $57 \%$ & $64 \%$ & $61 \%$ & $70 \%$ & $53 \%$ & $62 \%$ \\
\hline Increased somewhat & $10 \%$ & $5 \%$ & $13 \%$ & $11 \%$ & $13 \%$ & $6 \%$ & $12 \%$ & $7 \%$ & $14 \%$ & $7 \%$ \\
\hline Increased considerably & $0 \%$ & $0 \%$ & $0 \%$ & $0 \%$ & $0 \%$ & $0 \%$ & $0 \%$ & $0 \%$ & $0 \%$ & $0 \%$ \\
\hline Total & $100 \%$ & $100 \%$ & $100 \%$ & $100 \%$ & $100 \%$ & $100 \%$ & $100 \%$ & $100 \%$ & $100 \%$ & $100 \%$ \\
\hline Net percentage & $-25 \%$ & $-27 \%$ & $-16 \%$ & $-23 \%$ & $-18 \%$ & $-24 \%$ & $-16 \%$ & $-17 \%$ & $-19 \%$ & $-24 \%$ \\
\hline Diffusion index & $-14 \%$ & $-14 \%$ & $-10 \%$ & $-12 \%$ & $-12 \%$ & $-13 \%$ & $-9 \%$ & $-9 \%$ & $-12 \%$ & $-13 \%$ \\
\hline Mean & 2.72 & 2.72 & 2.79 & 2.76 & 2.77 & 2.75 & 2.81 & 2.83 & 2.76 & 2.74 \\
\hline Standard deviation & 0.72 & 0.59 & 0.74 & 0.67 & 0.77 & 0.62 & 0.71 & 0.56 & 0.78 & 0.63 \\
\hline Number of banks responding & 124 & 125 & 120 & 121 & 119 & 120 & 124 & 125 & 123 & 124 \\
\hline
\end{tabular}

Notes: Net percentage is defined as the difference between the sum of the percentages for "increased considerably" and "increased somewhat" and the sum of the percentages for "decreased somewhat" and "decreased considerably". The diffusion index is defined as the net percentage weighted according to the intensity of the response, giving lenders who have answered "considerably" a weight twice as high (score of 1) as lenders having answered "somewhat" (score of 0.5).

The mean and standard deviation are calculated by attributing the values 1 to 5 starting with the first possible answer and consequently for the other answers. These values are then multiplied with the corresponding (weighted) percentages.

\section{Chart 4}

\section{CHANGES IN DEMAND FOR LOANS OR CREDIT LINES TO} ENTERPRISES

(net percentages of banks reporting a positive contribution to demand)

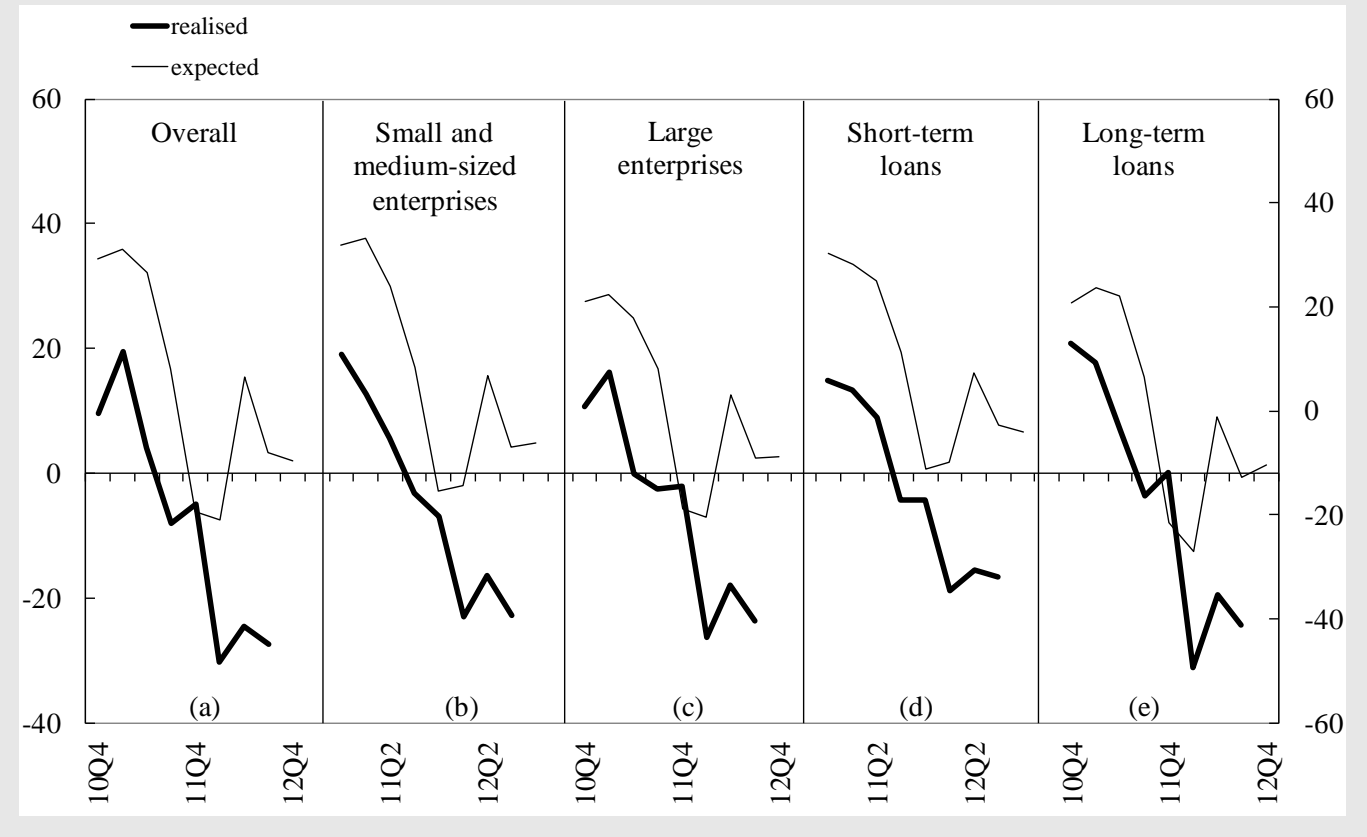


5. Over the past three months, how have the following factors affected the demand for loans or credit lines to enterprises?

\begin{tabular}{|l|c|c|c|c|c|c|}
\hline & -- & - & $\circ$ & + & ++ & NA \\
\hline A) Financing needs & & & & & & \\
Fixed investment & $2 \%$ & $36 \%$ & $51 \%$ & $5 \%$ & $0 \%$ & $7 \%$ \\
Inventories and working capital & $0 \%$ & $20 \%$ & $64 \%$ & $8 \%$ & $1 \%$ & $8 \%$ \\
Mergers/acquisitions and corporate restructuring & $1 \%$ & $18 \%$ & $69 \%$ & $2 \%$ & $0 \%$ & $10 \%$ \\
Debt restructuring & $0 \%$ & $1 \%$ & $78 \%$ & $15 \%$ & $1 \%$ & $6 \%$ \\
\hline B) Use of alternative finance & & & & & & \\
Internal financing & $1 \%$ & $11 \%$ & $81 \%$ & $2 \%$ & $0 \%$ & $6 \%$ \\
Loans from other banks & $0 \%$ & $6 \%$ & $87 \%$ & $1 \%$ & $0 \%$ & $6 \%$ \\
Loans from non-banks & $0 \%$ & $3 \%$ & $89 \%$ & $0 \%$ & $1 \%$ & $8 \%$ \\
Issuance of debt securities & $0 \%$ & $7 \%$ & $79 \%$ & $2 \%$ & $1 \%$ & $11 \%$ \\
Issuance of equity & $0 \%$ & $3 \%$ & $83 \%$ & $0 \%$ & $1 \%$ & $14 \%$ \\
\hline
\end{tabular}

\begin{tabular}{|c|c|c|c|c|c|c|c|c|}
\hline & \multicolumn{2}{|c|}{ NetP } & \multicolumn{2}{|c|}{ DI } & \multicolumn{2}{|c|}{$\mathrm{M}$} & \multicolumn{2}{|c|}{ SD } \\
\hline & Jul & Oct & Jul & Oct & Jul & Oct & Jul & Oct \\
\hline A) Financing needs & & & & & & & & \\
\hline Fixed investment & $-36 \%$ & $-33 \%$ & $-20 \%$ & $-18 \%$ & 2.56 & 2.62 & 0.70 & 0.65 \\
\hline Inventories and working capital & $-4 \%$ & $-11 \%$ & $-2 \%$ & $-5 \%$ & 2.95 & 2.89 & 0.65 & 0.59 \\
\hline Mergers/acquisitions and corporate restructuring & $-13 \%$ & $-17 \%$ & $-8 \%$ & $-9 \%$ & 2.83 & 2.80 & 0.56 & 0.51 \\
\hline Debt restructuring & $14 \%$ & $15 \%$ & $7 \%$ & $8 \%$ & 3.15 & 3.16 & 0.50 & 0.45 \\
\hline B) Use of alternative finance & & & & & & & & \\
\hline Internal financing & $-12 \%$ & $-9 \%$ & $-6 \%$ & $-5 \%$ & 2.87 & 2.90 & 0.46 & 0.41 \\
\hline Loans from other banks & $0 \%$ & $-4 \%$ & $1 \%$ & $-2 \%$ & 3.01 & 2.96 & 0.37 & 0.28 \\
\hline Loans from non-banks & $-1 \%$ & $-2 \%$ & $0 \%$ & $-1 \%$ & 2.99 & 2.98 & 0.16 & 0.26 \\
\hline Issuance of debt securities & $0 \%$ & $-5 \%$ & $0 \%$ & $-2 \%$ & 2.99 & 2.96 & 0.27 & 0.40 \\
\hline Issuance of equity & $2 \%$ & $-2 \%$ & $1 \%$ & $-1 \%$ & 3.02 & 2.99 & 0.15 & 0.28 \\
\hline
\end{tabular}

$\mathrm{NA}=$ Not available; NetP = Net percentage; $\mathrm{DI}=$ Diffusion index $; \mathrm{M}=$ Mean; $\mathrm{SD}=$ Standard deviation Notes: Column "Net percentage" is defined as the difference between the sum of "+ + " (contributed considerably to higher demand) and "+“ (contributed somewhat to higher demand) and the sum of "-" (contributed somewhat to lower demand) and “- -” (contributed considerably to lower demand). ”” means contributed to basically unchanged demand. The diffusion index is defined as the net percentage weighted according to the intensity of the response, giving lenders who have answered "considerably" a weight twice as high (score of 1 ) as lenders having answered "somewhat" (score of 0.5). 


\section{Chart 5a}

FACTORS AFFECTING DEMAND FOR LOANS AND CREDIT LINES TO ENTERPRISES

(net percentages of banks reporting a positive contribution to demand)

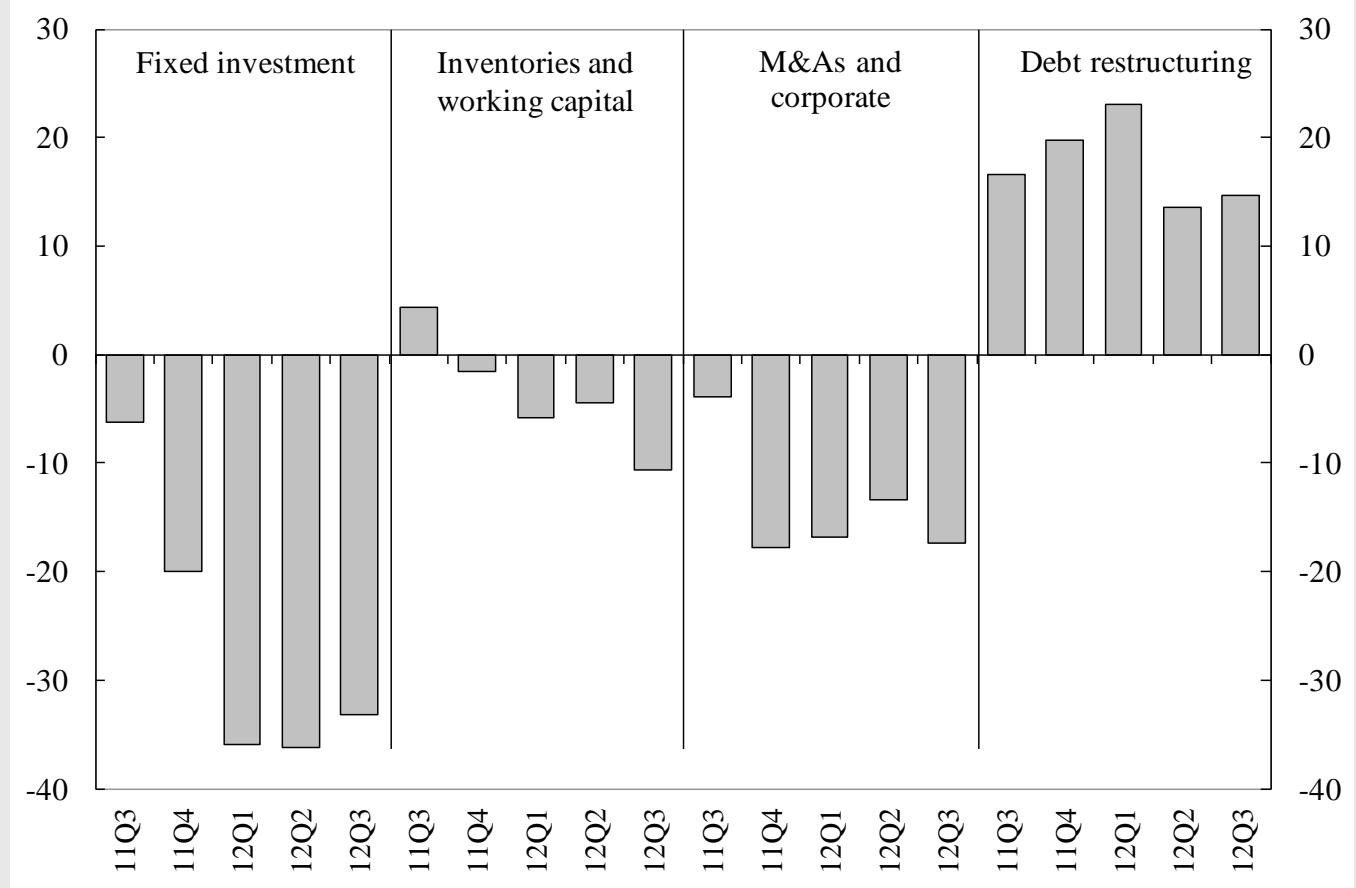




\section{Chart 5b}

FACTORS AFFECTING DEMAND FOR LOANS AND CREDIT LINES TO ENTERPRISES

(net percentages of banks reporting a positive contribution to demand)

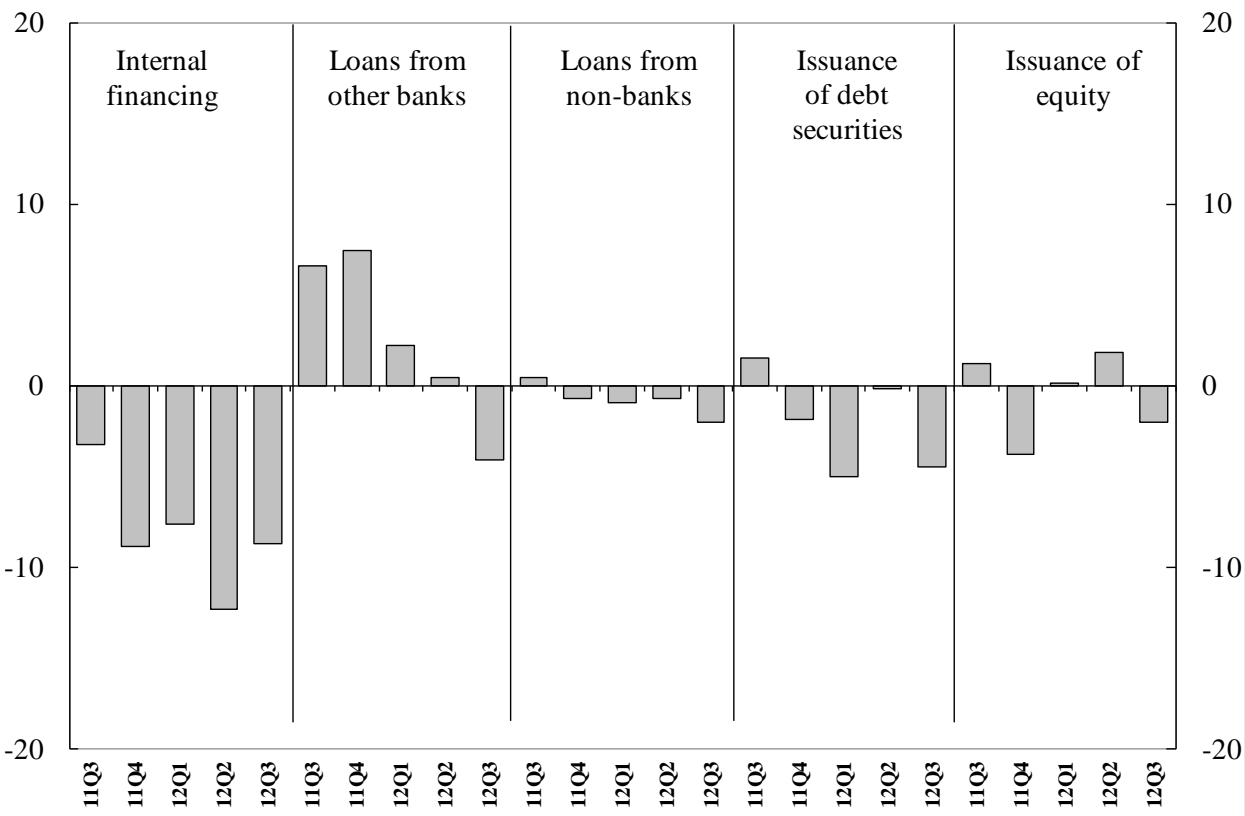

6. Please indicate how you expect your bank's credit standards as applied to the approval of loans or credit lines to enterprises to change over the next three months.

\begin{tabular}{|c|c|c|c|c|c|c|c|c|c|c|}
\hline & \multicolumn{2}{|c|}{ Overall } & \multicolumn{2}{|c|}{$\begin{array}{l}\text { Loans to small } \\
\text { and medium- } \\
\text { sized enterprises }\end{array}$} & \multicolumn{2}{|c|}{$\begin{array}{l}\text { Loans to large } \\
\text { enterprises }\end{array}$} & \multicolumn{2}{|c|}{ Short-term loans } & \multicolumn{2}{|c|}{ Long-term loans } \\
\hline & Jul & Oct & Jul & Oct & Jul & Oct & Jul & Oct & Jul & Oct \\
\hline Tighten considerably & $0 \%$ & $0 \%$ & $0 \%$ & $0 \%$ & $2 \%$ & $0 \%$ & $0 \%$ & $0 \%$ & $0 \%$ & $0 \%$ \\
\hline Tighten somewhat & $10 \%$ & $13 \%$ & $9 \%$ & $8 \%$ & $10 \%$ & $10 \%$ & $4 \%$ & $8 \%$ & $13 \%$ & $15 \%$ \\
\hline Remain basically unchanged & $89 \%$ & $87 \%$ & $90 \%$ & $92 \%$ & $88 \%$ & $90 \%$ & $95 \%$ & $91 \%$ & $87 \%$ & $85 \%$ \\
\hline Ease somewhat & $1 \%$ & $0 \%$ & $2 \%$ & $1 \%$ & $0 \%$ & $0 \%$ & $1 \%$ & $1 \%$ & $1 \%$ & $0 \%$ \\
\hline Ease considerably & $0 \%$ & $0 \%$ & $0 \%$ & $0 \%$ & $0 \%$ & $0 \%$ & $0 \%$ & $0 \%$ & $0 \%$ & $0 \%$ \\
\hline Total & $100 \%$ & $100 \%$ & $100 \%$ & $100 \%$ & $100 \%$ & $100 \%$ & $100 \%$ & $100 \%$ & $100 \%$ & $100 \%$ \\
\hline Net percentage & $10 \%$ & $13 \%$ & $7 \%$ & $7 \%$ & $12 \%$ & $10 \%$ & $4 \%$ & $6 \%$ & $12 \%$ & $15 \%$ \\
\hline Diffusion index & $5 \%$ & $6 \%$ & $4 \%$ & $4 \%$ & $7 \%$ & $5 \%$ & $2 \%$ & $3 \%$ & $6 \%$ & $8 \%$ \\
\hline Mean & 2.90 & 2.87 & 2.93 & 2.93 & 2.86 & 2.90 & 2.96 & 2.94 & 2.88 & 2.85 \\
\hline Standard deviation & 0.35 & 0.36 & 0.34 & 0.30 & 0.42 & 0.32 & 0.24 & 0.31 & 0.37 & 0.38 \\
\hline Number of banks responding & 123 & 125 & 119 & 121 & 118 & 120 & 123 & 125 & 122 & 124 \\
\hline
\end{tabular}

Notes: Net percentage is defined as the difference between the sum of the percentages for "tighten considerably" and "tighten somewhat" and the sum of the percentages for "ease somewhat" and "ease considerably". The diffusion index is defined as the net percentage weighted according to the intensity of the response, giving lenders who have answered "considerably" a weight twice as high (score of 1) as lenders having answered "somewhat" (score of 0.5).

The mean and standard deviation are calculated by attributing the values 1 to 5 starting with the first possible answer and consequently for the other answers. These values are then multiplied with the corresponding (weighted) percentages. 


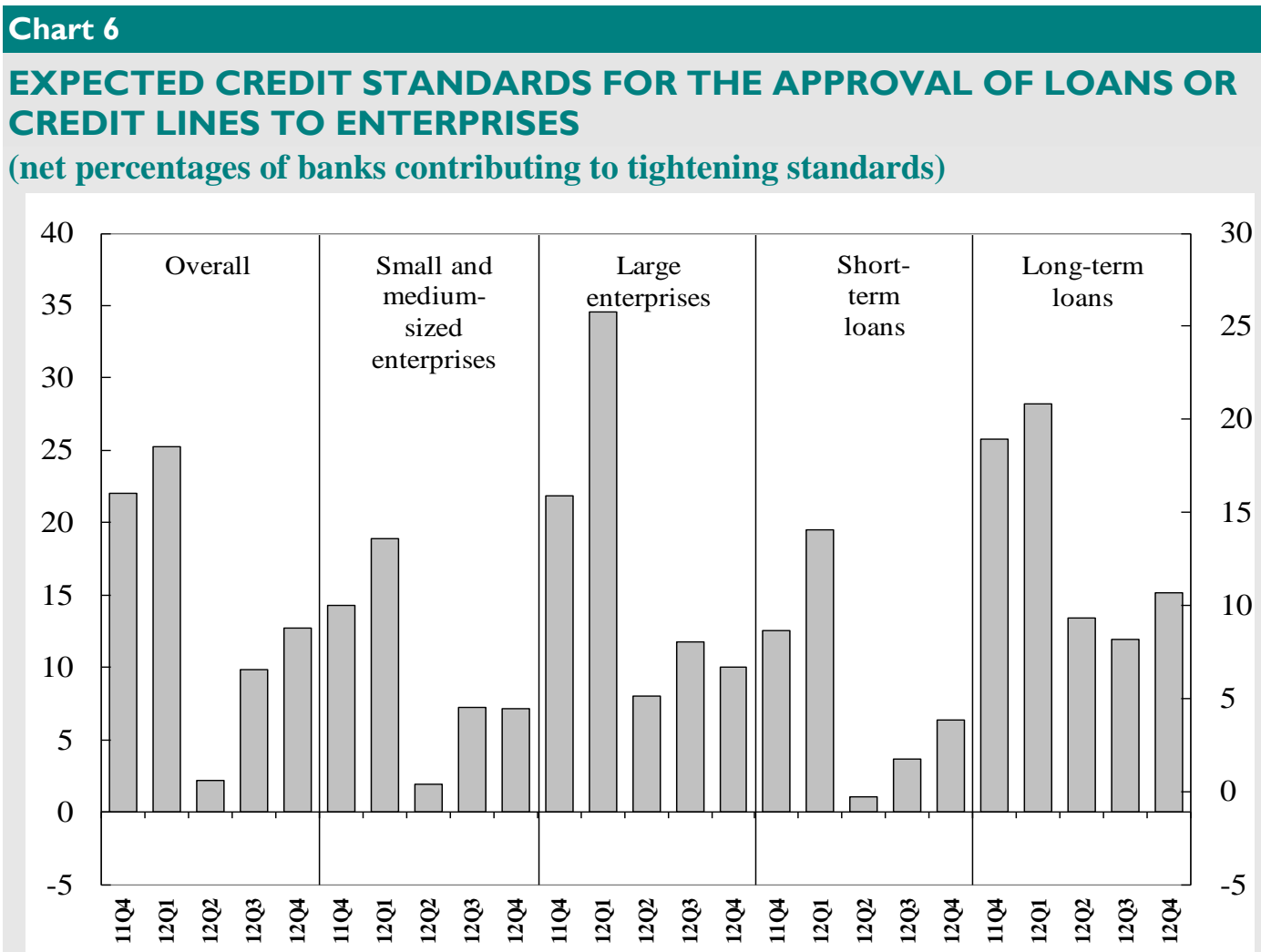

7. Please indicate how you expect demand for loans or credit lines to enterprises to change at your bank over the next three months (apart from normal seasonal fluctuations).

\begin{tabular}{|c|c|c|c|c|c|c|c|c|c|c|}
\hline & \multicolumn{2}{|c|}{ Overall } & \multicolumn{2}{|c|}{$\begin{array}{c}\text { Loans to small } \\
\text { and medium- } \\
\text { sized enterprises }\end{array}$} & \multicolumn{2}{|c|}{$\begin{array}{l}\text { Loans to large } \\
\text { enterprises }\end{array}$} & \multicolumn{2}{|c|}{ Short-term loans } & \multicolumn{2}{|c|}{ Long-term loans } \\
\hline & Jul & Oct & Jul & Oct & Jul & Oct & Jul & Oct & Jul & Oct \\
\hline Decrease considerably & $0 \%$ & $0 \%$ & $0 \%$ & $0 \%$ & $1 \%$ & $1 \%$ & $0 \%$ & $1 \%$ & $1 \%$ & $1 \%$ \\
\hline Decrease somewhat & $14 \%$ & $18 \%$ & $15 \%$ & $18 \%$ & $13 \%$ & $14 \%$ & $11 \%$ & $13 \%$ & $18 \%$ & $15 \%$ \\
\hline Remain basically unchanged & $81 \%$ & $74 \%$ & $77 \%$ & $70 \%$ & $80 \%$ & $79 \%$ & $81 \%$ & $76 \%$ & $75 \%$ & $79 \%$ \\
\hline Increase somewhat & $6 \%$ & $8 \%$ & $8 \%$ & $12 \%$ & $5 \%$ & $6 \%$ & $8 \%$ & $10 \%$ & $6 \%$ & $5 \%$ \\
\hline Increase considerably & $0 \%$ & $0 \%$ & $0 \%$ & $0 \%$ & $1 \%$ & $0 \%$ & $1 \%$ & $0 \%$ & $0 \%$ & $0 \%$ \\
\hline Total & $100 \%$ & $100 \%$ & $100 \%$ & $100 \%$ & $100 \%$ & $100 \%$ & $100 \%$ & $100 \%$ & $100 \%$ & $100 \%$ \\
\hline Net percentage & $-8 \%$ & $-10 \%$ & $-7 \%$ & $-6 \%$ & $-9 \%$ & $-9 \%$ & $-3 \%$ & $-4 \%$ & $-13 \%$ & $-11 \%$ \\
\hline Diffusion index & $-4 \%$ & $-5 \%$ & $-4 \%$ & $-3 \%$ & $-5 \%$ & $-5 \%$ & $-1 \%$ & $-2 \%$ & $-7 \%$ & $-6 \%$ \\
\hline Mean & 2.92 & 2.90 & 2.93 & 2.94 & 2.90 & 2.91 & 2.98 & 2.95 & 2.87 & 2.89 \\
\hline Standard deviation & 0.45 & 0.52 & 0.50 & 0.57 & 0.53 & 0.50 & 0.49 & 0.53 & 0.52 & 0.49 \\
\hline Number of banks responding & 123 & 125 & 119 & 121 & 118 & 119 & 122 & 125 & 122 & 124 \\
\hline
\end{tabular}

Notes: Net percentage is defined as the difference between the sum of the percentages for "increase considerably" and "increase somewhat" and the sum of the percentages for "decrease somewhat" and "decrease considerably". The diffusion index is defined as the net percentage weighted according to the intensity of the response, giving lenders who have answered "considerably" a weight twice as high (score of 1) as lenders having answered "somewhat" (score of 0.5 ).

The mean and standard deviation are calculated by attributing the values 1 to 5 starting with the first possible answer and consequently for the other answers. These values are then multiplied with the corresponding (weighted) percentages. 


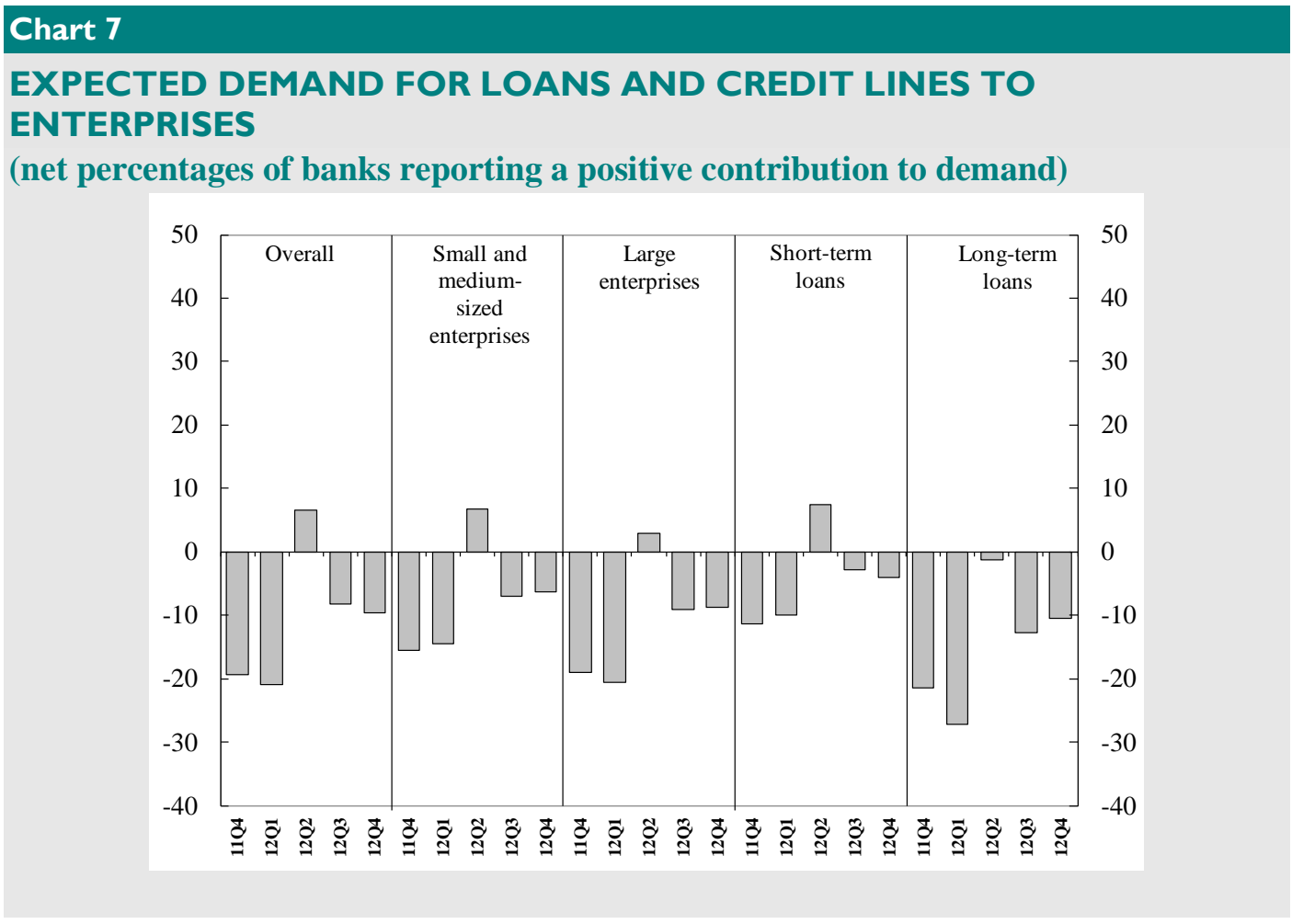

\section{LOANS TO HOUSEHOLDS}

8. Over the past three months, how have your bank's credit standards as applied to the approval of loans to households changed?

\begin{tabular}{|l|cc|cc|}
\hline \multirow{2}{*}{} & \multicolumn{2}{|c|}{$\begin{array}{c}\text { Loans for house } \\
\text { purchase }\end{array}$} & $\begin{array}{c}\text { Consumer credit } \\
\text { and other lending }\end{array}$ \\
\cline { 2 - 5 } & Jul & Oct & Jul & Oct \\
\hline Tightened considerably & $0 \%$ & $0 \%$ & $1 \%$ & $0 \%$ \\
Tightened somewhat & $14 \%$ & $13 \%$ & $9 \%$ & $4 \%$ \\
Remained basically unchanged & $86 \%$ & $88 \%$ & $87 \%$ & $95 \%$ \\
Eased somewhat & $1 \%$ & $0 \%$ & $3 \%$ & $1 \%$ \\
Eased considerably & $0 \%$ & $0 \%$ & $0 \%$ & $0 \%$ \\
Total & $100 \%$ & $100 \%$ & $100 \%$ & $100 \%$ \\
\hline Net percentage & $\mathbf{1 3 \%}$ & $\mathbf{1 2} \%$ & $\mathbf{7 \%}$ & $\mathbf{3} \%$ \\
Diffusion index & $\mathbf{6 \%}$ & $\mathbf{6 \%}$ & $\mathbf{4 \%}$ & $\mathbf{2 \%}$ \\
Mean & 2.87 & 2.88 & 2.93 & 2.97 \\
Standard deviation & 0.38 & 0.35 & 0.40 & 0.23 \\
\hline Number of banks responding & $\mathbf{1 1 7}$ & $\mathbf{1 1 8}$ & $\mathbf{1 1 7}$ & $\mathbf{1 1 9}$ \\
\hline
\end{tabular}

Notes: Net percentage is defined as the difference between the sum of the percentages for "tightened considerably" and "tightened somewhat" and the sum of the percentages for "eased somewhat" and "eased considerably". The diffusion index is defined as the net percentage weighted according to the intensity of the response, giving lenders who have answered "considerably" a weight twice as high (score of 1) as lenders having answered "somewhat" (score of 0.5).

The mean and standard deviation are calculated by attributing the values 1 to 5 starting with the first possible answer and consequently for the other answers. These values are then multiplied with the corresponding (weighted) percentages. 


\section{Chart 8}

\section{CREDIT STANDARDS APPLIED TO THE APPROVAL OF LOANS TO}

HOUSEHOLDS

(net percentages of banks reporting tightening credit standards)

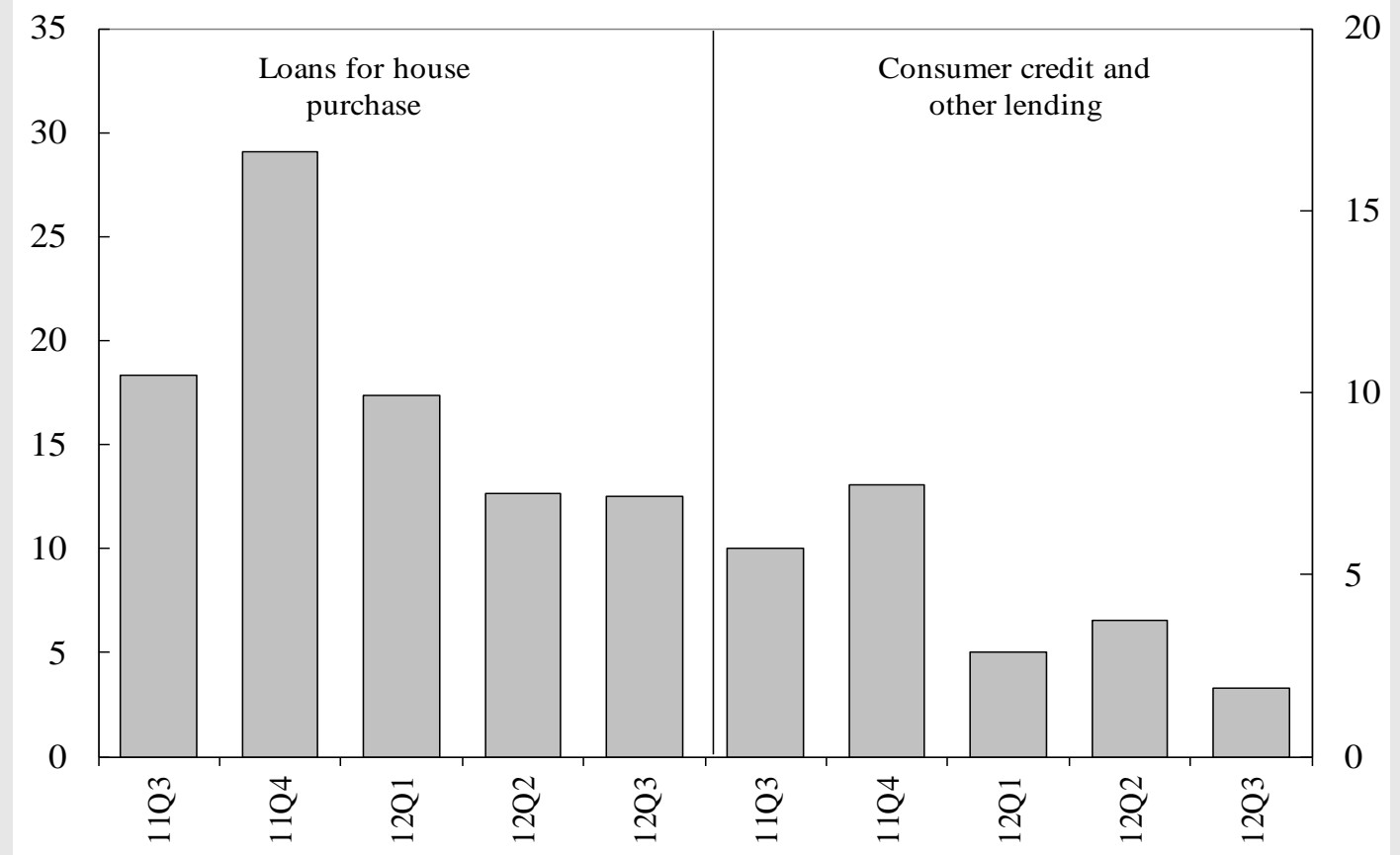


9. Over the past three months, how have the following factors affected your bank's credit standards as applied to the approval of loans to households for house purchase?

\begin{tabular}{|l|c|c|c|c|c|c|}
\hline & -- & - & $\circ$ & + & ++ & NA \\
\hline A) Cost of funds and balance sheet constraints & $1 \%$ & $11 \%$ & $73 \%$ & $1 \%$ & $1 \%$ & $14 \%$ \\
\hline B) Pressure from competition & & & & & & \\
Competition from other banks & $0 \%$ & $2 \%$ & $83 \%$ & $2 \%$ & $0 \%$ & $13 \%$ \\
Competition from non-banks & $0 \%$ & $1 \%$ & $83 \%$ & $1 \%$ & $0 \%$ & $15 \%$ \\
\hline C) Perception of risk & & & & & & \\
& & & & & & \\
Expectations regarding general economic activity & $1 \%$ & $9 \%$ & $77 \%$ & $0 \%$ & $0 \%$ & $13 \%$ \\
Housing market prospects & $2 \%$ & $8 \%$ & $75 \%$ & $2 \%$ & $0 \%$ & $13 \%$ \\
\hline
\end{tabular}

\begin{tabular}{|c|c|c|c|c|c|c|c|c|}
\hline & \multicolumn{2}{|c|}{ NetP } & \multicolumn{2}{|c|}{ DI } & \multicolumn{2}{|c|}{$\mathrm{M}$} & \multicolumn{2}{|c|}{ SD } \\
\hline & Jul & Oct & Jul & Oct & Jul & Oct & Jul & Oct \\
\hline A) Cost of funds and balance sheet constraints & $14 \%$ & $9 \%$ & $7 \%$ & $4 \%$ & 2.84 & 2.92 & 0.41 & 0.51 \\
\hline B) Pressure from competition & & & & & & & & \\
\hline Competition from other banks & $0 \%$ & $0 \%$ & $0 \%$ & $0 \%$ & 3.00 & 3.00 & 0.11 & 0.23 \\
\hline Competition from non-banks & $0 \%$ & $0 \%$ & $0 \%$ & $0 \%$ & 3.00 & 3.00 & 0.07 & 0.20 \\
\hline C) Perception of risk & & & & & & & & \\
\hline Expectations regarding general economic activity & $11 \%$ & $10 \%$ & $6 \%$ & $6 \%$ & 2.88 & 2.88 & 0.36 & 0.38 \\
\hline Housing market prospects & $9 \%$ & $8 \%$ & $5 \%$ & $5 \%$ & 2.90 & 2.90 & 0.40 & 0.44 \\
\hline
\end{tabular}

NA = Not available; NetP = Net percentage; $\mathrm{DI}=$ Diffusion index; $\mathrm{M}=$ Mean; $\mathrm{SD}=$ Standard deviation Notes: Column "Net percentage" is defined as the difference between the sum of "- -" (contributed considerably to tightening) and "_." (contributed somewhat to tightening) and the sum of "+”" (contributed somewhat to easing) and "+ +" (contributed considerably to easing). "” means contributed to basically unchanged. The diffusion index is defined as the net percentage weighted according to the intensity of the response, giving lenders who have answered "considerably" a weight twice as high (score of 1 ) as lenders having answered "somewhat" (score of 0.5). 


\section{Chart 9}

FACTORS AFFECTING CREDIT STANDARDS APPLIED TO THE APPROVAL OF LOANS TO HOUSEHOLDS

(net percentages of banks contributing to tightening credit standards)

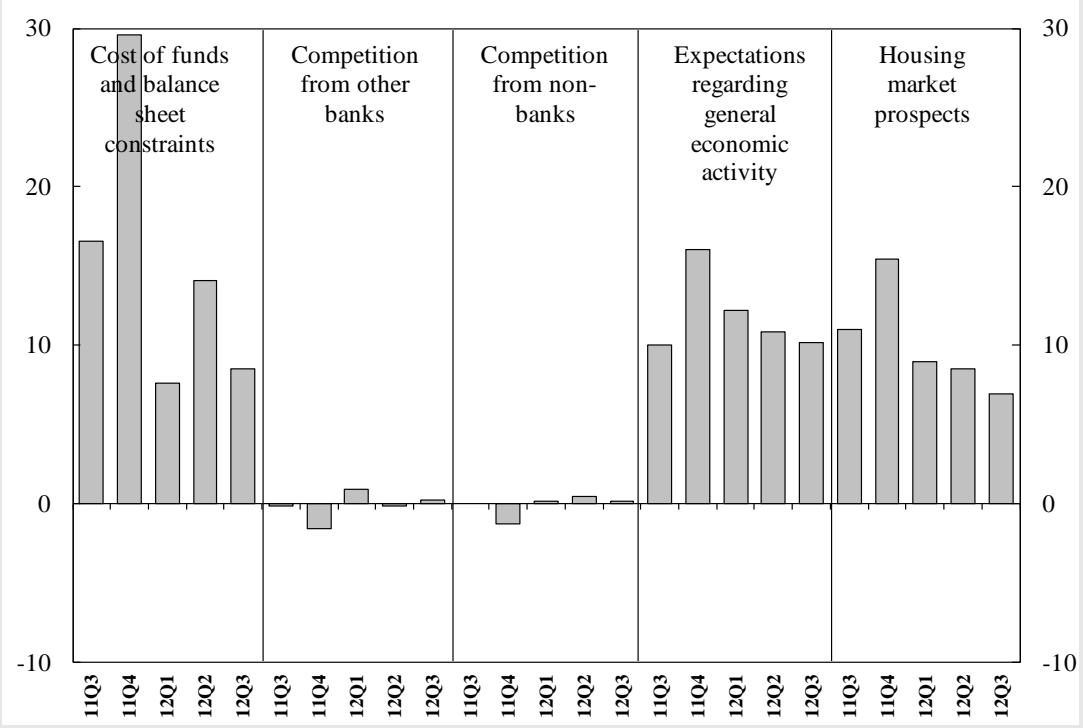

10. Over the past three months, how have your bank's conditions and terms for approving loans to households for house purchase changed?

\begin{tabular}{|l|c|c|c|c|c|c|}
\hline & -- & - & $\circ$ & + & ++ & NA \\
\hline A) Price & & & & & & \\
Your bank's margin on average loans & $0 \%$ & $17 \%$ & $67 \%$ & $4 \%$ & $0 \%$ & $13 \%$ \\
Your bank's margin on riskier loans & $2 \%$ & $19 \%$ & $64 \%$ & $2 \%$ & $0 \%$ & $13 \%$ \\
\hline B) Other conditions and terms & & & & & & \\
Collateral requirements & $0 \%$ & $2 \%$ & $86 \%$ & $0 \%$ & $0 \%$ & $13 \%$ \\
Loan-to-value ratio & $0 \%$ & $8 \%$ & $79 \%$ & $0 \%$ & $0 \%$ & $13 \%$ \\
Maturity & $0 \%$ & $4 \%$ & $83 \%$ & $1 \%$ & $0 \%$ & $13 \%$ \\
Non-interest rate charges & $0 \%$ & $3 \%$ & $84 \%$ & $0 \%$ & $0 \%$ & $13 \%$ \\
\hline
\end{tabular}

Summary statistics

\begin{tabular}{|c|c|c|c|c|c|c|c|c|}
\hline & \multicolumn{2}{|c|}{ NetP } & \multicolumn{2}{|c|}{ DI } & \multicolumn{2}{|c|}{$\mathrm{M}$} & \multicolumn{2}{|c|}{ SD } \\
\hline & Jul & Oct & Jul & Oct & Jul & Oct & Jul & Oct \\
\hline A) Price & & & & & & & & \\
\hline Your bank's margin on average loans & $15 \%$ & $14 \%$ & $7 \%$ & $7 \%$ & 2.84 & 2.85 & 0.52 & 0.48 \\
\hline Your bank's margin on riskier loans & $21 \%$ & $19 \%$ & $12 \%$ & $11 \%$ & 2.75 & 2.77 & 0.58 & 0.54 \\
\hline B) Other conditions and terms & & & & & & & & \\
\hline Collateral requirements & $1 \%$ & $2 \%$ & $1 \%$ & $1 \%$ & 2.99 & 2.98 & 0.23 & 0.14 \\
\hline Loan-to-value ratio & $6 \%$ & $8 \%$ & $3 \%$ & $4 \%$ & 2.93 & 2.91 & 0.27 & 0.31 \\
\hline Maturity & $5 \%$ & $3 \%$ & $2 \%$ & $2 \%$ & 2.94 & 2.96 & 0.27 & 0.23 \\
\hline Non-interest rate charges & $1 \%$ & $3 \%$ & $1 \%$ & $2 \%$ & 2.99 & 2.97 & 0.17 & 0.19 \\
\hline
\end{tabular}

$\mathrm{NA}=$ Not available; NetP = Net percentage; $\mathrm{DI}=$ Diffusion index; $\mathrm{M}=$ Mean; $\mathrm{SD}=$ Standard deviation

Notes: Column "Net percentage" is defined as the difference between the sum of "- - " (tightened considerably) and "-“ (tightened somewhat) and the sum of "+” (eased somewhat) and "+ +" (eased considerably). "” means remained basically unchanged. The diffusion index is defined as the net percentage weighted according to the intensity of the response, giving lenders who have answered "considerably" a weight twice as high (score of 1) as lenders having answered "somewhat" (score of 0.5 ). 


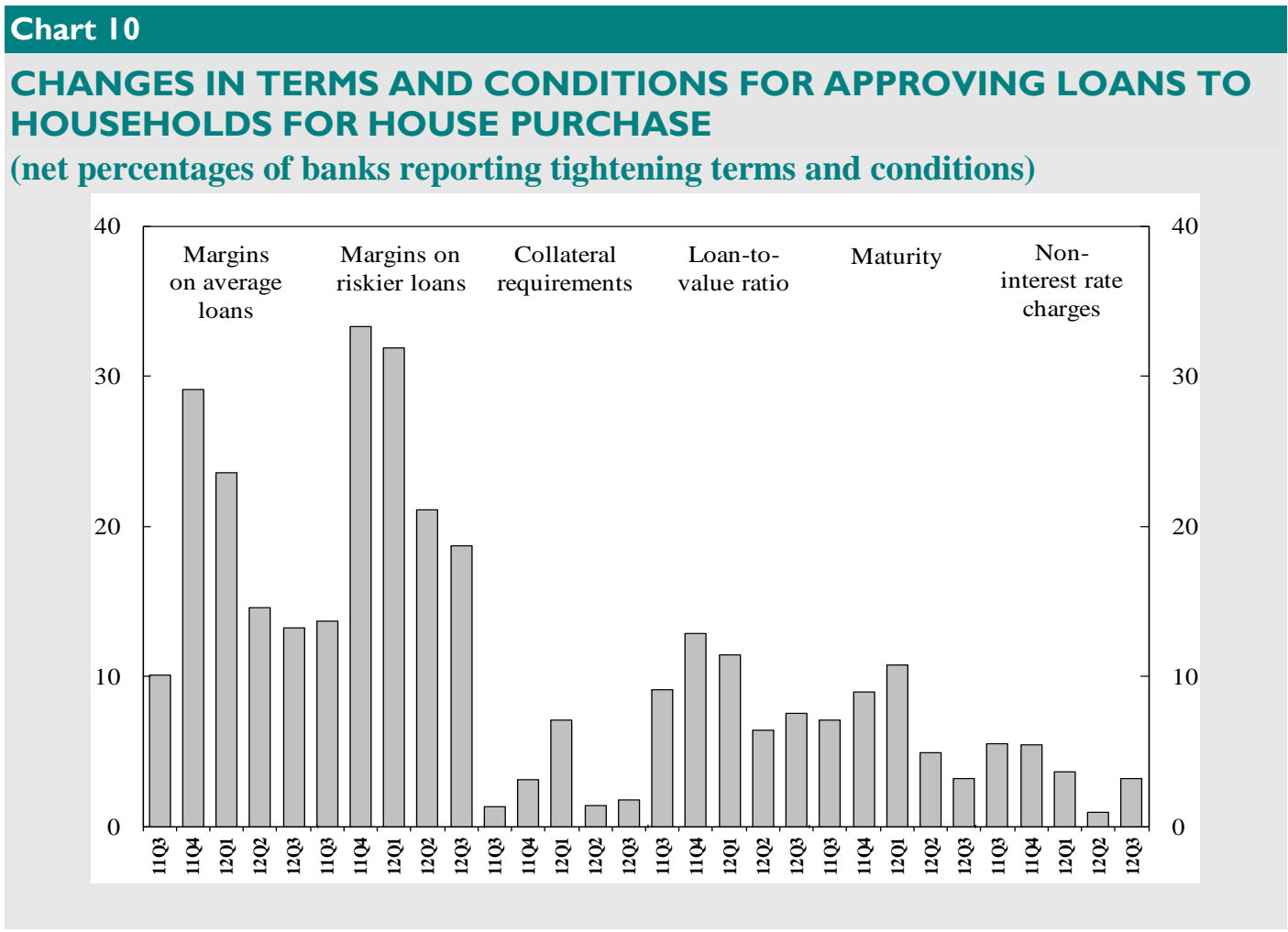

11. Over the past three months, how have the following factors affected your bank's credit standards as applied to the approval of consumer credit and other lending to households (as described in question 8)?

\begin{tabular}{|l|c|c|c|c|c|c|}
\hline & -- & - & $\circ$ & + & ++ & NA \\
\hline A) Cost of funds and balance sheet constraints & $1 \%$ & $3 \%$ & $84 \%$ & $1 \%$ & $1 \%$ & $11 \%$ \\
\hline B) Pressure from competition & & & & & & \\
Competition from other banks & $0 \%$ & $1 \%$ & $88 \%$ & $1 \%$ & $0 \%$ & $10 \%$ \\
Competition from non-banks & $0 \%$ & $0 \%$ & $87 \%$ & $2 \%$ & $0 \%$ & $11 \%$ \\
\hline C) Perception of risk & & & & & & \\
Expectations regarding general economic activity & $2 \%$ & $7 \%$ & $81 \%$ & $1 \%$ & $0 \%$ & $9 \%$ \\
Creditworthiness of consumers & $1 \%$ & $4 \%$ & $85 \%$ & $1 \%$ & $0 \%$ & $9 \%$ \\
Risk on collateral demanded & $1 \%$ & $2 \%$ & $85 \%$ & $1 \%$ & $0 \%$ & $12 \%$ \\
\hline
\end{tabular}

\begin{tabular}{|c|c|c|c|c|c|c|c|c|}
\hline & \multicolumn{2}{|c|}{ NetP } & \multicolumn{2}{|c|}{$\mathrm{DI}$} & \multicolumn{2}{|c|}{$\mathrm{M}$} & \multicolumn{2}{|c|}{ SD } \\
\hline & Jul & Oct & Jul & Oct & Jul & Oct & Jul & Oct \\
\hline A) Cost of funds and balance sheet constraints & $8 \%$ & $1 \%$ & $5 \%$ & $0 \%$ & 2.90 & 3.00 & 0.39 & 0.38 \\
\hline B) Pressure from competition & & & & & & & & \\
\hline Competition from other banks & $-3 \%$ & $-1 \%$ & $-1 \%$ & $-1 \%$ & 3.03 & 3.01 & 0.18 & 0.16 \\
\hline Competition from non-banks & $-1 \%$ & $-2 \%$ & $0 \%$ & $-1 \%$ & 3.01 & 3.02 & 0.09 & 0.16 \\
\hline C) Perception of risk & & & & & & & & \\
\hline Expectations regarding general economic activity & $8 \%$ & $8 \%$ & $5 \%$ & $5 \%$ & 2.91 & 2.91 & 0.38 & 0.39 \\
\hline Creditworthiness of consumers & $7 \%$ & $4 \%$ & $4 \%$ & $3 \%$ & 2.92 & 2.95 & 0.38 & 0.31 \\
\hline Risk on collateral demanded & $3 \%$ & $2 \%$ & $2 \%$ & $1 \%$ & 2.96 & 2.98 & 0.26 & 0.29 \\
\hline
\end{tabular}

NA = Not available; NetP = Net percentage; DI = Diffusion index; M = Mean; SD = Standard deviation

Notes: Column "Net percentage" is defined as the difference between the sum of "- -"(contributed considerably to tightening) and "-“(contributed somewhat to tightening) and the sum of "+" (contributed somewhat to easing) and "+ +" (contributed considerably to easing). "” means contributed to basically unchanged. The diffusion index is defined as the net percentage weighted according to the intensity of the response, giving lenders who have answered "considerably" a weight twice as high (score of 1 ) as lenders having answered "somewhat" (score of 0.5). 
Chart II

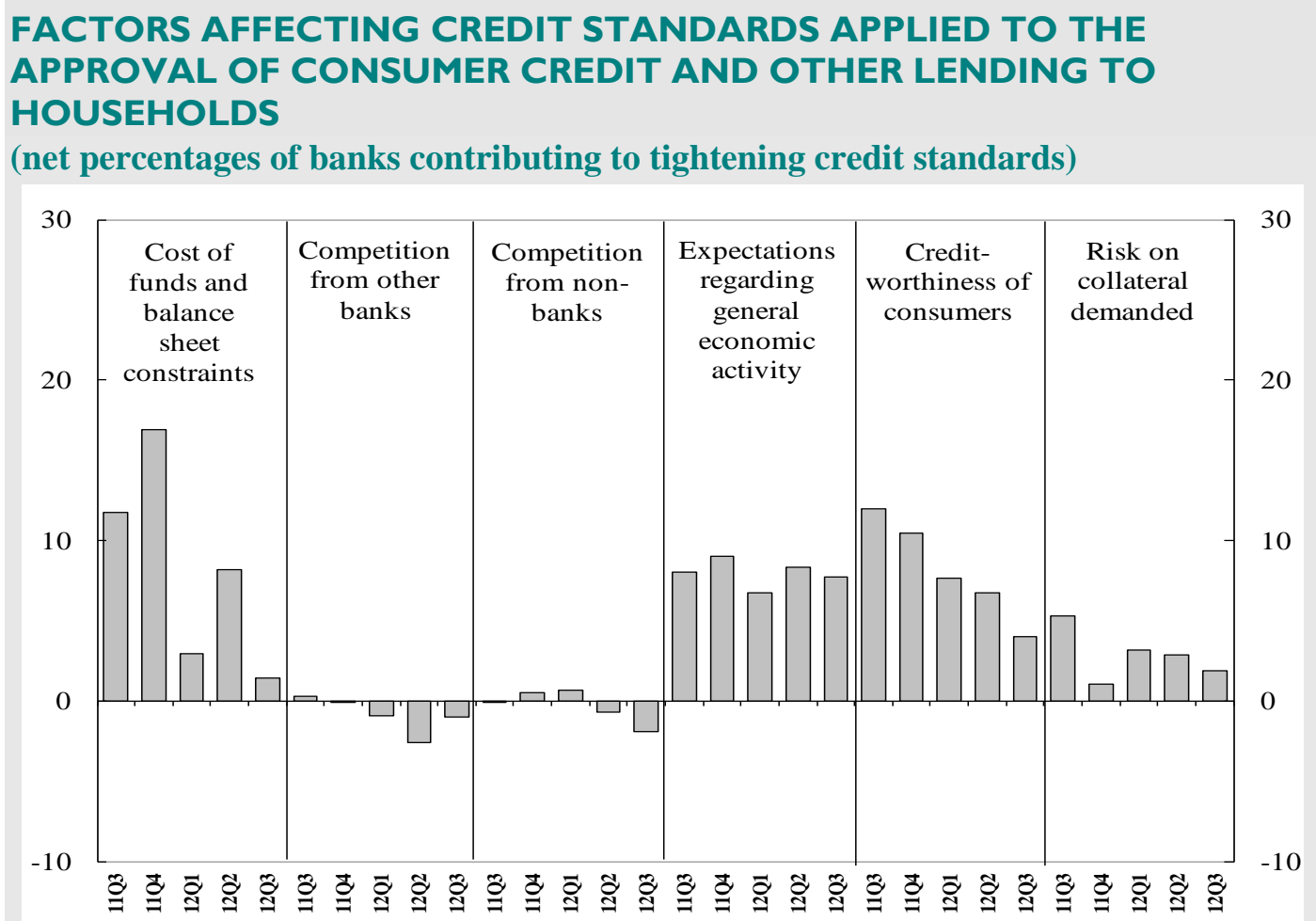

12. Over the past three months, how have your bank's conditions and terms for approving consumer credit and other lending to households changed?

\begin{tabular}{|l|c|c|c|c|c|c|}
\hline & -- & - & $\circ$ & + & ++ & NA \\
\hline A) Price & & & & & & \\
Your bank's margin on average loans & $0 \%$ & $14 \%$ & $76 \%$ & $1 \%$ & $0 \%$ & $9 \%$ \\
Your bank's margin on riskier loans & $3 \%$ & $12 \%$ & $75 \%$ & $0 \%$ & $0 \%$ & $10 \%$ \\
\hline B) Other conditions and terms & & & & & & \\
Collateral requirements & $0 \%$ & $2 \%$ & $87 \%$ & $0 \%$ & $0 \%$ & $11 \%$ \\
Maturity & $0 \%$ & $0 \%$ & $90 \%$ & $1 \%$ & $0 \%$ & $9 \%$ \\
Non-interest rate charges & $0 \%$ & $3 \%$ & $88 \%$ & $0 \%$ & $0 \%$ & $9 \%$ \\
\hline
\end{tabular}

Summary statistics
\begin{tabular}{|l|c|c|c|c|c|c|c|c|}
\hline \multicolumn{1}{|c|}{} & \multicolumn{2}{|c|}{ NetP } & \multicolumn{2}{|c|}{ DI } & \multicolumn{2}{|c|}{ M } & \multicolumn{2}{c|}{ SD } \\
\cline { 2 - 10 } & Jul & Oct & Jul & Oct & Jul & Oct & Jul & Oct \\
\hline A) Price & & & & & & & & \\
Your bank's margin on average loans & $11 \%$ & $13 \%$ & $6 \%$ & $7 \%$ & 2.88 & 2.85 & 0.52 & 0.40 \\
Your bank's margin on riskier loans & $13 \%$ & $14 \%$ & $8 \%$ & $8 \%$ & 2.83 & 2.82 & 0.48 & 0.48 \\
\hline B) Other conditions and terms & & & & & & & & \\
Collateral requirements & $3 \%$ & $2 \%$ & $1 \%$ & $1 \%$ & 2.97 & 2.98 & 0.18 & 0.14 \\
Maturity & $2 \%$ & $0 \%$ & $1 \%$ & $0 \%$ & 2.98 & 3.00 & 0.14 & 0.09 \\
Non-interest rate charges & $1 \%$ & $3 \%$ & $0 \%$ & $1 \%$ & 2.99 & 2.97 & 0.24 & 0.17 \\
\hline
\end{tabular}

NA = Not available; NetP = Net percentage; $\mathrm{DI}=$ Diffusion index; $\mathrm{M}=$ Mean; $\mathrm{SD}=$ Standard deviation Notes: Column "Net percentage" is defined as the difference between the sum of "- - " (tightened considerably) and "-“ (tightened somewhat) and the sum of "+” (eased somewhat) and “+ +" (eased considerably). ””, means remained basically unchanged. The diffusion index is defined as the net percentage weighted according to the intensity of the response, giving lenders who have answered "considerably" a weight twice as high (score of 1 ) as lenders having answered "somewhat" (score of 0.5 ). 


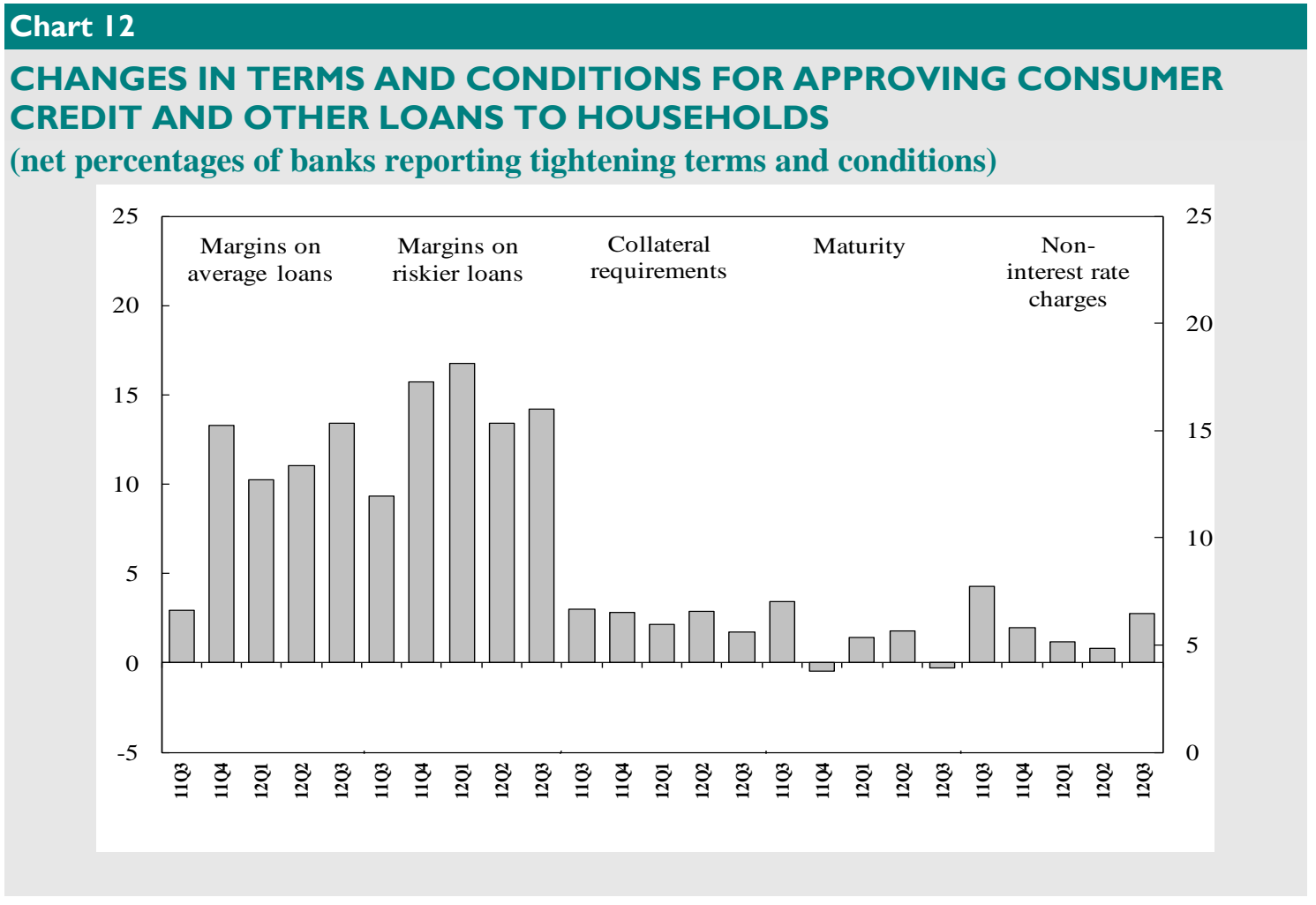

13. Over the past three months, how has the demand for loans to households changed at your bank, apart from normal seasonal fluctuations?

\begin{tabular}{|l|cc|cc|}
\hline \multirow{2}{*}{} & \multicolumn{2}{|c|}{$\begin{array}{c}\text { Loans for house } \\
\text { purchase }\end{array}$} & $\begin{array}{c}\text { Consumer credit } \\
\text { and other } \\
\text { lending }\end{array}$ \\
\cline { 2 - 5 } & Jul & Oct & Jul & Oct \\
\hline Decreased considerably & $5 \%$ & $3 \%$ & $4 \%$ & $2 \%$ \\
Decreased somewhat & $31 \%$ & $34 \%$ & $31 \%$ & $25 \%$ \\
Remained basically unchanged & $51 \%$ & $51 \%$ & $58 \%$ & $67 \%$ \\
Increased somewhat & $12 \%$ & $10 \%$ & $7 \%$ & $4 \%$ \\
Increased considerably & $2 \%$ & $3 \%$ & $1 \%$ & $2 \%$ \\
Total & $100 \%$ & $100 \%$ & $100 \%$ & $100 \%$ \\
\hline Net percentage & $\mathbf{- 2 1 \%}$ & $\mathbf{- 2 5 \%}$ & $\mathbf{- 2 7 \%}$ & $\mathbf{- 2 2} \%$ \\
Diffusion index & $\mathbf{- 1 2 \%}$ & $\mathbf{- 1 3 \%}$ & $\mathbf{- 1 5 \%}$ & $\mathbf{- 1 1 \%}$ \\
Mean & 2.77 & 2.75 & 2.70 & 2.78 \\
Standard deviation & 0.83 & 0.80 & 0.72 & 0.66 \\
\hline Number of banks responding & $\mathbf{1 1 7}$ & $\mathbf{1 1 8}$ & $\mathbf{1 1 9}$ & $\mathbf{1 2 0}$ \\
\hline
\end{tabular}

Notes: Net percentage is defined as the difference between the sum of the percentages for "increased considerably" and "increased somewhat" and the sum of the percentages for "decreased somewhat" and "decreased considerably". The diffusion index is defined as the net percentage weighted according to the intensity of the response, giving lenders who have answered "considerably" a weight twice as high (score of 1) as lenders having answered "somewhat" (score of 0.5).

The mean and standard deviation are calculated by attributing the values 1 to 5 starting with the first possible answer and consequently for the other answers. These values are then multiplied with the corresponding (weighted) percentages. 


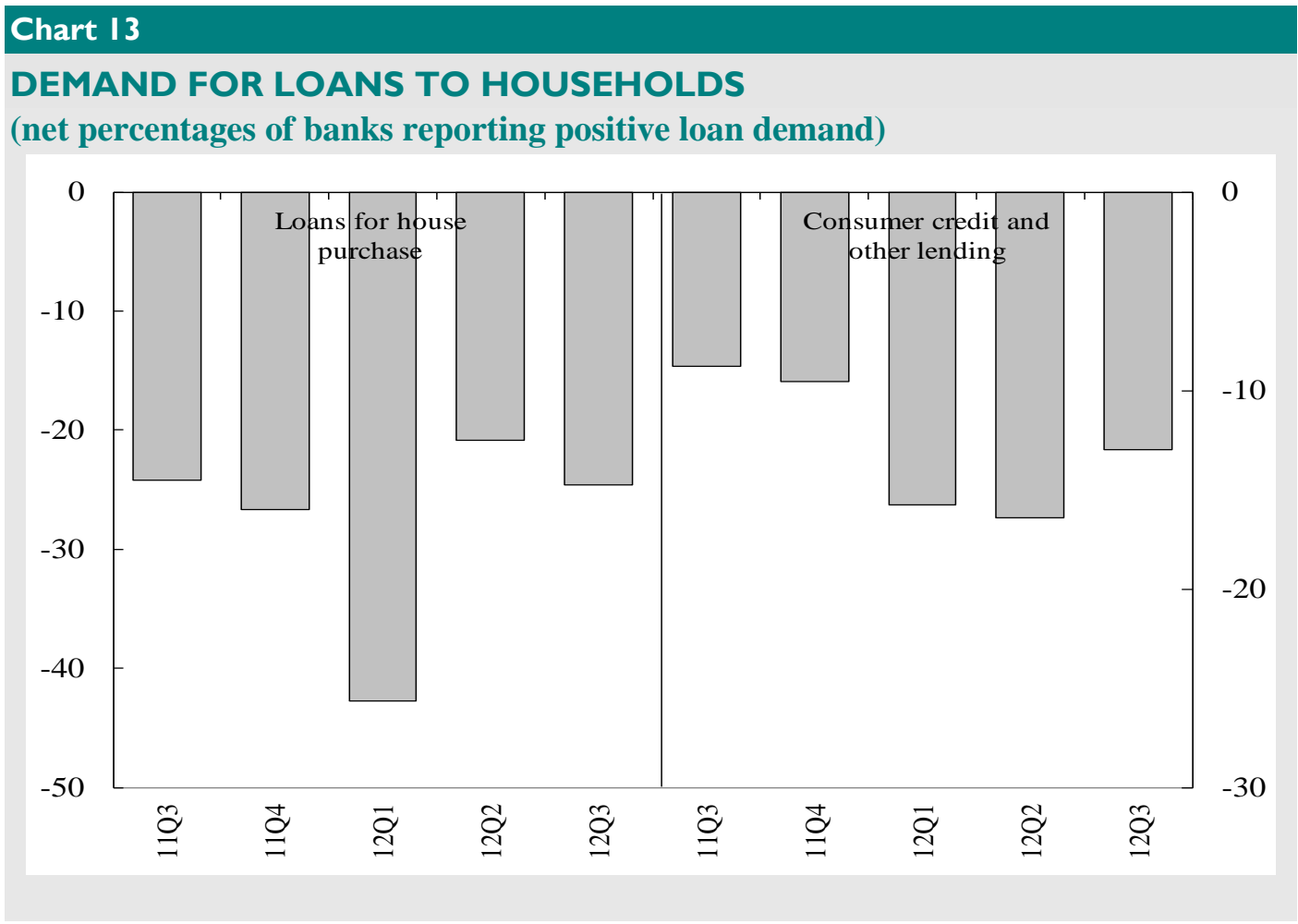

14. Over the past three months, how have the following factors affected the demand for loans to households for house purchase (as described in question 13)?

\begin{tabular}{|l|c|c|c|c|c|c|}
\hline & -- & - & $\circ$ & + & ++ & NA \\
\hline A) Financing needs & & & & & & \\
Housing market prospects & $3 \%$ & $22 \%$ & $53 \%$ & $10 \%$ & $0 \%$ & $13 \%$ \\
Consumer confidence & $2 \%$ & $27 \%$ & $52 \%$ & $6 \%$ & $0 \%$ & $13 \%$ \\
Non-housing related consumption expenditure & $1 \%$ & $13 \%$ & $72 \%$ & $2 \%$ & $0 \%$ & $13 \%$ \\
\hline B) Use of alternative finance & & & & & & \\
Household savings & $1 \%$ & $8 \%$ & $79 \%$ & $0 \%$ & $0 \%$ & $13 \%$ \\
Loans from other banks & $0 \%$ & $4 \%$ & $81 \%$ & $1 \%$ & $0 \%$ & $14 \%$ \\
Other sources of finance & $0 \%$ & $2 \%$ & $85 \%$ & $0 \%$ & $0 \%$ & $13 \%$ \\
\hline
\end{tabular}

\begin{tabular}{|c|c|c|c|c|c|c|c|c|}
\hline & \multicolumn{2}{|c|}{ NetP } & \multicolumn{2}{|c|}{$\mathrm{DI}$} & \multicolumn{2}{|c|}{$\mathrm{M}$} & \multicolumn{2}{|c|}{ SD } \\
\hline & Jul & Oct & Jul & Oct & Jul & Oct & Jul & Oct \\
\hline A) Financing needs & & & & & & & & \\
\hline Housing market prospects & $-25 \%$ & $-14 \%$ & $-13 \%$ & $-8 \%$ & 2.70 & 2.82 & 0.71 & 0.70 \\
\hline Consumer confidence & $-27 \%$ & $-23 \%$ & $-16 \%$ & $-13 \%$ & 2.64 & 2.72 & 0.71 & 0.65 \\
\hline Non-housing related consumption expenditure & $-14 \%$ & $-12 \%$ & $-7 \%$ & $-6 \%$ & 2.84 & 2.87 & 0.42 & 0.45 \\
\hline B) Use of alternative finance & & & & & & & & \\
\hline Household savings & $-8 \%$ & $-9 \%$ & $-5 \%$ & $-5 \%$ & 2.89 & 2.89 & 0.49 & 0.36 \\
\hline Loans from other banks & $-3 \%$ & $-3 \%$ & $-2 \%$ & $-2 \%$ & 2.97 & 2.96 & 0.29 & 0.25 \\
\hline Other sources of finance & $1 \%$ & $-2 \%$ & $1 \%$ & $-1 \%$ & 3.02 & 2.98 & 0.19 & 0.15 \\
\hline
\end{tabular}

NA = Not available; NetP = Net percentage; $\mathrm{DI}=$ Diffusion index; $\mathrm{M}=$ Mean; SD = Standard deviation Notes: Column "Net percentage" is defined as the difference between the sum of " + + "(contributed considerably to higher demand) and "+"(contributed somewhat to higher demand) and the sum of "-" (contributed somewhat to lower demand) and “- -” (contributed considerably to lower demand). ”” means contributed to basically unchanged demand. The diffusion index is defined as the net percentage weighted according to the intensity of the response, giving lenders who have answered "considerably" a weight twice as high (score of 1 ) as lenders having answered "somewhat" (score of 0.5 ). 


\section{Chart 14}

FACTORS AFFECTING DEMAND FOR LOANS TO HOUSEHOLDS FOR HOUSE PURCHASE

(net percentages of banks reporting a positive contribution to demand)

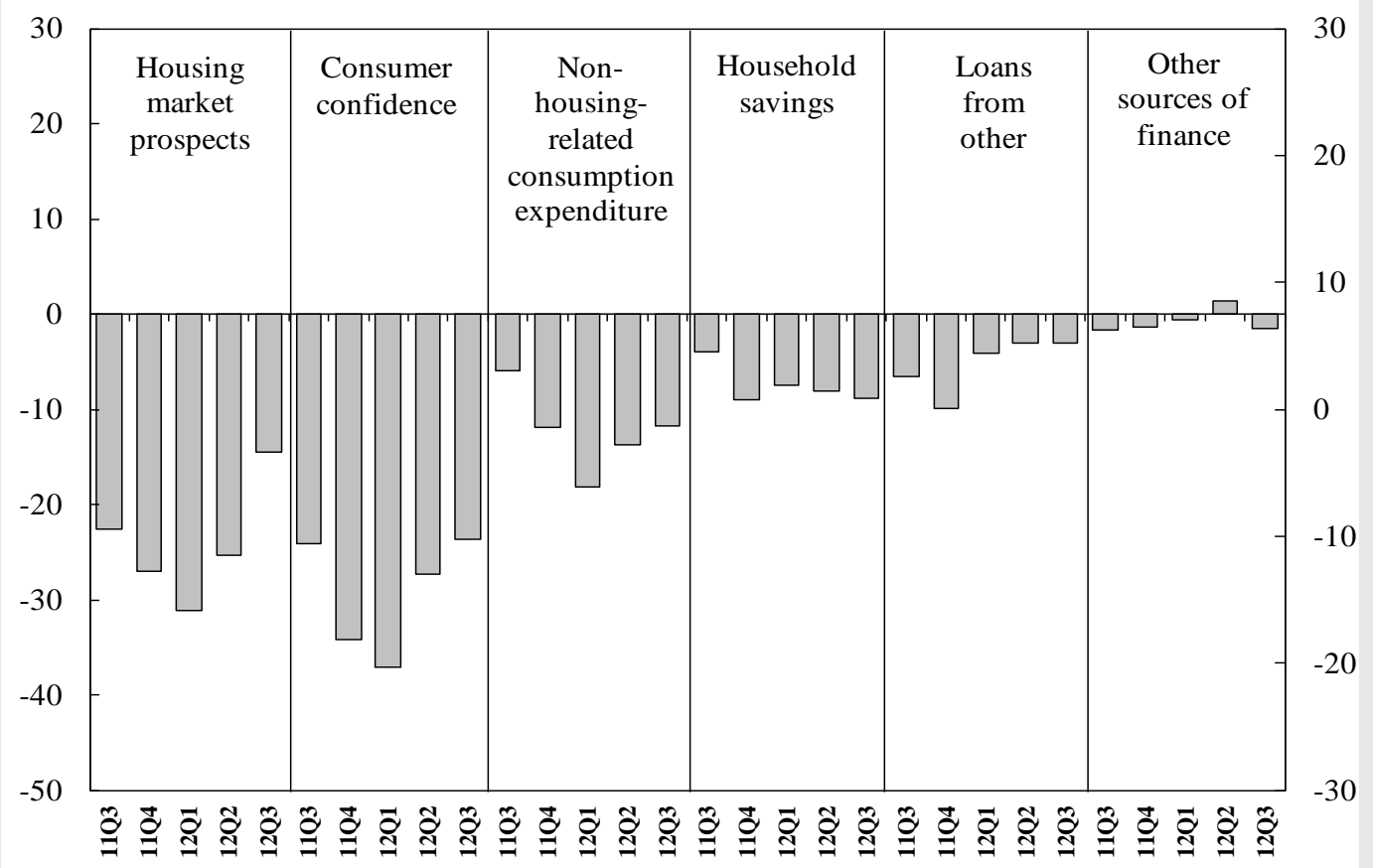


15. Over the past three months, how have the following factors affected the demand for consumer credit and other lending to households (as described in question 13)?

\begin{tabular}{|l|c|c|c|c|c|c|}
\hline & -- & - & $\circ$ & + & ++ & NA \\
\hline A) Financing needs & & & & & & \\
Spending on durable consumer goods & $3 \%$ & $21 \%$ & $62 \%$ & $6 \%$ & $0 \%$ & $10 \%$ \\
Consumer confidence & $3 \%$ & $22 \%$ & $64 \%$ & $3 \%$ & $0 \%$ & $9 \%$ \\
Securities purchases & $0 \%$ & $1 \%$ & $81 \%$ & $0 \%$ & $0 \%$ & $18 \%$ \\
\hline B) Use of alternative finance & & & & & & \\
Household savings & $0 \%$ & $7 \%$ & $84 \%$ & $1 \%$ & $0 \%$ & $9 \%$ \\
Loans from other banks & $0 \%$ & $5 \%$ & $83 \%$ & $2 \%$ & $0 \%$ & $10 \%$ \\
Other sources of finance & $0 \%$ & $3 \%$ & $86 \%$ & $1 \%$ & $0 \%$ & $11 \%$ \\
\hline
\end{tabular}

Summary statistics

\begin{tabular}{|l|c|c|c|c|c|c|c|c|}
\hline \multirow{2}{*}{} & \multicolumn{2}{|c|}{ NetP } & \multicolumn{2}{|c|}{ DI } & \multicolumn{2}{|c|}{ M } & \multicolumn{2}{c|}{ SD } \\
\cline { 2 - 8 } & Jul & Oct & Jul & Oct & Jul & Oct & Jul & Oct \\
\hline A) Financing needs & & & & & & & & \\
Spending on durable consumer goods & $-28 \%$ & $-18 \%$ & $-16 \%$ & $-10 \%$ & 2.64 & 2.79 & 0.66 & 0.61 \\
Consumer confidence & $-26 \%$ & $-22 \%$ & $-14 \%$ & $-12 \%$ & 2.70 & 2.73 & 0.59 & 0.58 \\
Securities purchases & $-2 \%$ & $-1 \%$ & $-2 \%$ & $0 \%$ & 2.97 & 2.99 & 0.26 & 0.09 \\
\hline B) Use of alternative finance & & & & & & & & \\
Hous ehold savings & $-11 \%$ & $-6 \%$ & $-6 \%$ & $-3 \%$ & 2.88 & 2.94 & 0.40 & 0.29 \\
Loans from other banks & $-4 \%$ & $-3 \%$ & $-2 \%$ & $-2 \%$ & 2.95 & 2.97 & 0.35 & 0.28 \\
Other sources of finance & $-2 \%$ & $-3 \%$ & $-1 \%$ & $-1 \%$ & 2.99 & 2.97 & 0.22 & 0.21 \\
\hline
\end{tabular}

NA = Not available; NetP = Net percentage; $\mathrm{DI}=$ Diffusion index; $\mathrm{M}=$ Mean; SD = Standard deviation

Notes: Column "Net percentage" is defined as the difference between the sum of "+ +"(responsible for considerable increase) and "+“(responsible for increase) and the sum of "-” (responsible for decrease) and "- " (responsible for considerable decrease). "o" means responsible for neither decrease nor increase. The diffusion index is defined as the net percentage weighted according to the intensity of the response, giving lenders who have answered "considerably" a weight twice as high (score of 1 ) as lenders having answered “somewhat” (score of 0.5).

\section{Chart 15}

FACTORS AFFECTING DEMAND FOR CONSUMER CREDIT AND OTHER LENDING TO HOUSEHOLDS

(net percentages of banks reporting a positive contribution to demand)

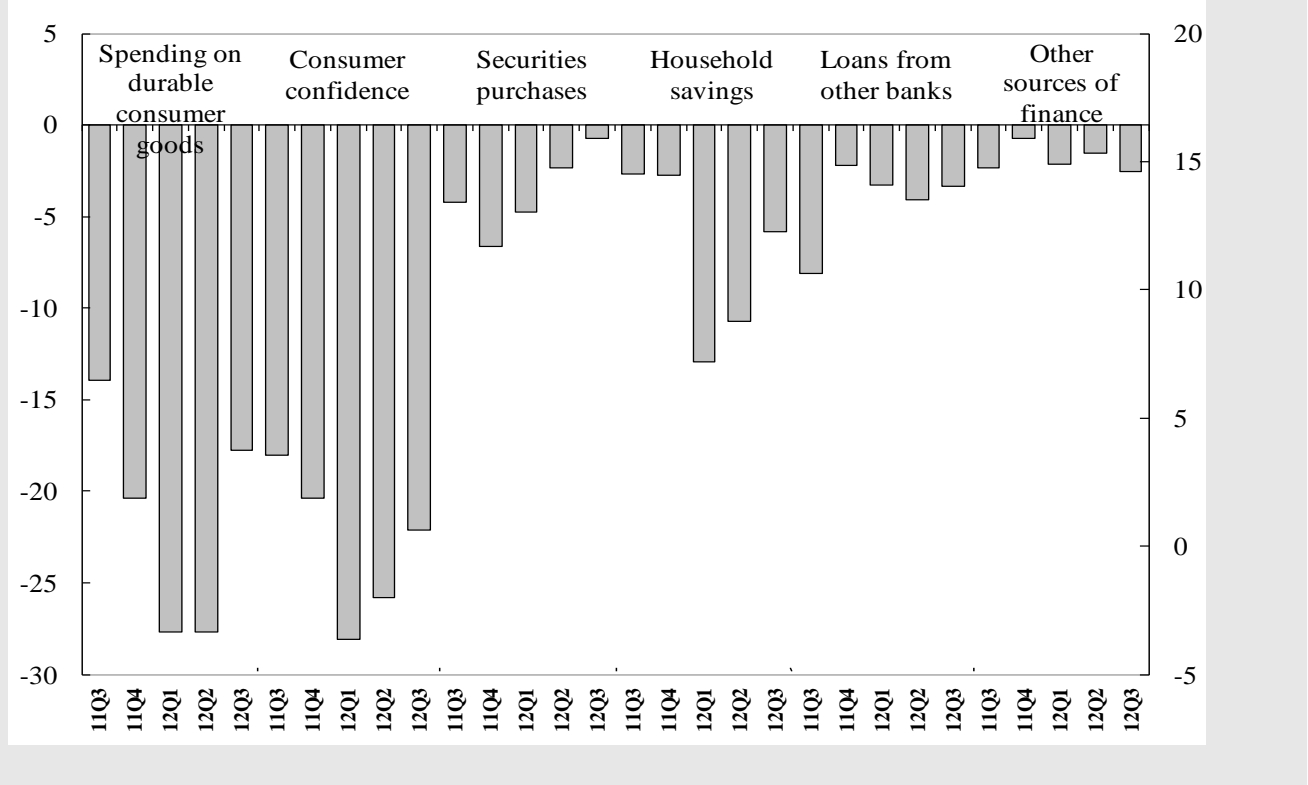


16. Please indicate how you expect your bank's credit standards as applied to the approval of loans to households to change over the next three months.

\begin{tabular}{|l|cc|cc|}
\hline \multirow{2}{*}{} & \multicolumn{2}{|c|}{$\begin{array}{c}\text { Loans for house } \\
\text { purchase }\end{array}$} & $\begin{array}{c}\text { Consumer credit } \\
\text { and other } \\
\text { lending }\end{array}$ \\
\cline { 2 - 5 } & Jul & Oct & Jul & Oct \\
\hline Tighten considerably & $0 \%$ & $0 \%$ & $1 \%$ & $0 \%$ \\
Tighten somewhat & $6 \%$ & $9 \%$ & $2 \%$ & $2 \%$ \\
Remain basically unchanged & $93 \%$ & $90 \%$ & $96 \%$ & $97 \%$ \\
Ease somewhat & $1 \%$ & $0 \%$ & $1 \%$ & $1 \%$ \\
Ease considerably & $0 \%$ & $0 \%$ & $0 \%$ & $0 \%$ \\
Total & $100 \%$ & $100 \%$ & $100 \%$ & $100 \%$ \\
\hline Net percentage & $\mathbf{5 \%}$ & $\mathbf{9 \%}$ & $\mathbf{2 \%}$ & $\mathbf{2 \%}$ \\
Diffusion index & $\mathbf{3 \%}$ & $\mathbf{4 \%}$ & $\mathbf{1 \%}$ & $\mathbf{1 \%}$ \\
Mean & 2.95 & 2.91 & 2.97 & 2.98 \\
Standard deviation & 0.28 & 0.32 & 0.26 & 0.17 \\
\hline Number of banks responding & $\mathbf{1 1 6}$ & $\mathbf{1 1 8}$ & $\mathbf{1 1 5}$ & $\mathbf{1 1 8}$ \\
\hline
\end{tabular}

Notes: Net percentage is defined as the difference between the sum of the percentages for "tighten considerably" and "tighten somewhat" and the sum of the percentages for "ease somewhat" and "ease considerably". The diffusion index is defined as the net percentage weighted according to the intensity of the response, giving lenders who have answered "considerably" a weight twice as high (score of 1) as lenders having answered "somewhat" (score of 0.5).

The mean and standard deviation are calculated by attributing the values 1 to 5 starting with the first possible answer and consequently for the other answers. These values are then multiplied with the corresponding (weighted) percentages.

\section{Chart 16}

\section{EXPECTED CREDIT STANDARDS FOR LOANS TO HOUSEHOLDS} (net percentages of banks expecting tightening credit standards)

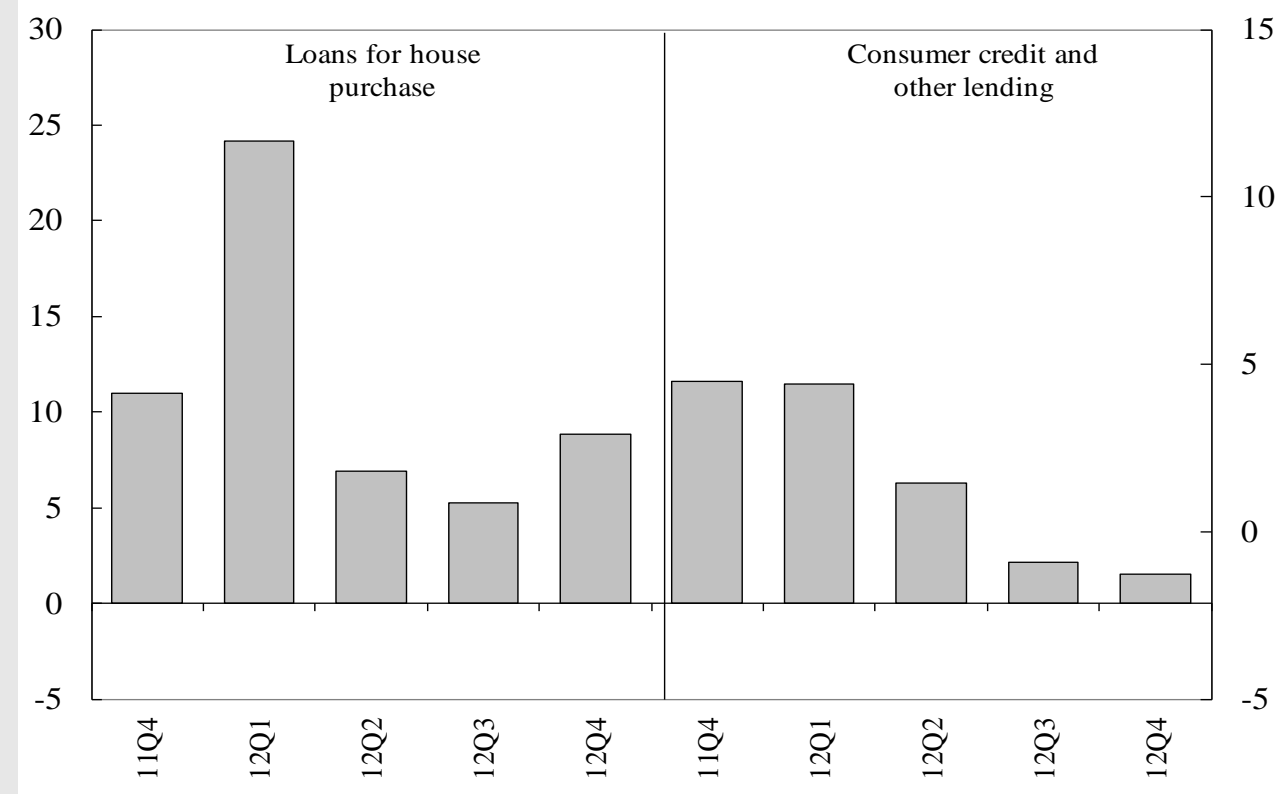


17. Please indicate how you expect demand for loans to households to change over the next three months at your bank (apart from normal seasonal fluctuations).

\begin{tabular}{|l|cc|cc|}
\hline \multirow{2}{*}{} & \multicolumn{2}{|c|}{$\begin{array}{c}\text { Loans for house } \\
\text { purchase }\end{array}$} & $\begin{array}{c}\text { Consumer credit } \\
\text { and other } \\
\text { lending }\end{array}$ \\
\cline { 2 - 5 } & Jul & Oct & Jul & Oct \\
\hline Decrease considerably & $1 \%$ & $0 \%$ & $1 \%$ & $0 \%$ \\
Decrease somewhat & $20 \%$ & $20 \%$ & $9 \%$ & $16 \%$ \\
Remain basically unchanged & $69 \%$ & $69 \%$ & $89 \%$ & $80 \%$ \\
Increase somewhat & $11 \%$ & $11 \%$ & $1 \%$ & $4 \%$ \\
Increase considerably & $0 \%$ & $0 \%$ & $0 \%$ & $0 \%$ \\
Total & $100 \%$ & $100 \%$ & $100 \%$ & $100 \%$ \\
\hline Net percentage & $\mathbf{- 1 0 \%}$ & $\mathbf{- 1 0 \%}$ & $\mathbf{- 8 \%}$ & $\mathbf{- 1 2 \%}$ \\
Diffusion index & $\mathbf{- 5 \%}$ & $\mathbf{- 5 \%}$ & $\mathbf{- 5 \%}$ & $\mathbf{- 6 \%}$ \\
Mean & 2.90 & 2.91 & 2.90 & 2.88 \\
Standard deviation & 0.58 & 0.57 & 0.41 & 0.46 \\
\hline Number of banks responding & $\mathbf{1 1 6}$ & $\mathbf{1 1 8}$ & $\mathbf{1 1 8}$ & $\mathbf{1 1 9}$ \\
\hline
\end{tabular}

Notes: Net percentage is defined as the difference between the sum of the percentages for "increase considerably" and "increase somewhat" and the sum of the percentages for "decrease somewhat" and "decrease considerably". The diffusion index is defined as the net percentage weighted according to the intensity of the response, giving lenders who have answered "considerably" a weight twice as high (score of 1) as lenders having answered "somewhat" (score of 0.5).

The mean and standard deviation are calculated by attributing the values 1 to 5 starting with the first possible answer and consequently for the other answers. These values are then multiplied with the corresponding (weighted) percentages.

\section{Chart 17}

\section{EXPECTED DEMAND FOR LOANS TO HOUSEHOLDS}

(net percentages of banks expecting positive loan demand)

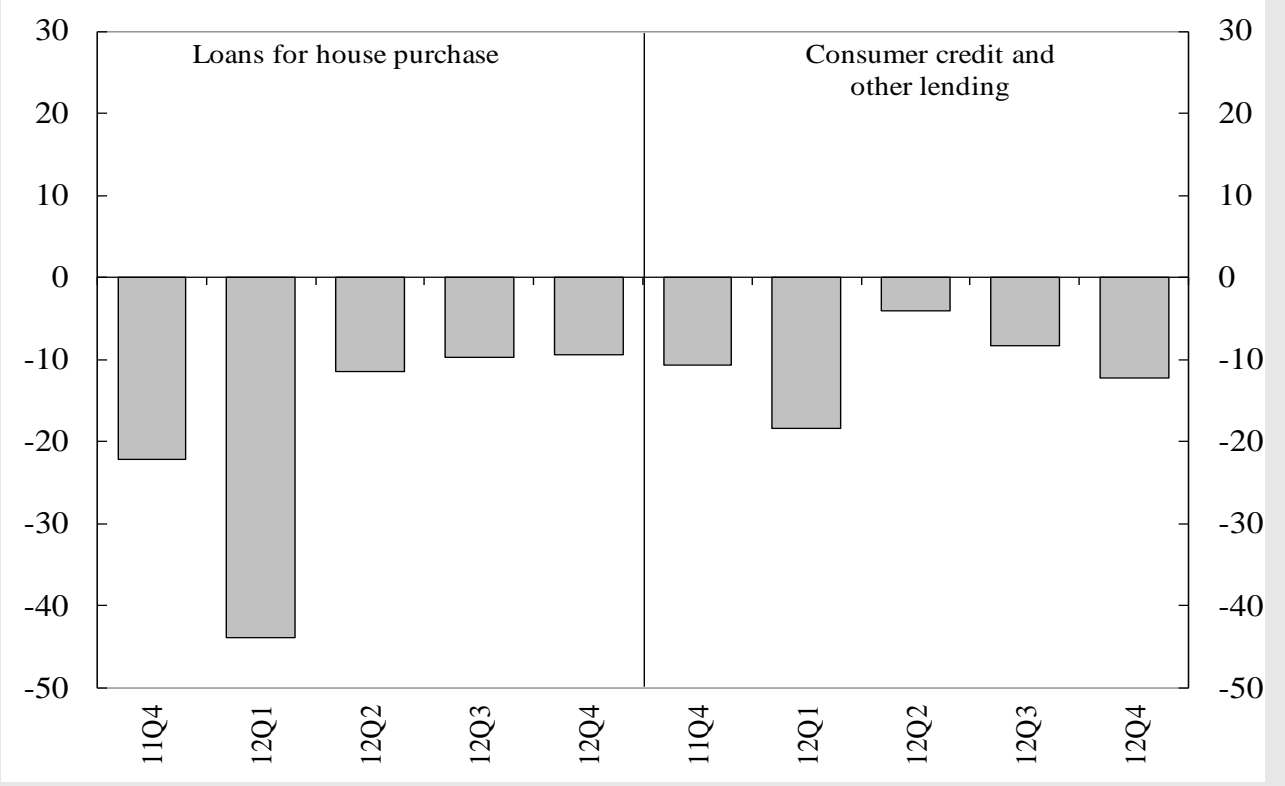




\section{ANNEX 2: RESULTS FOR THE AD HOC QUESTIONS}

i. As a result of the situation in financial markets ${ }^{(1)}$, has your market access changed when tapping your usual sources of wholesale and retail funding and/or has your ability to transfer risk changed over the past three months, or are you expecting this access/activity to change over the next three months? ${ }^{1}$

\begin{tabular}{|c|c|c|c|c|c|c|c|c|c|c|c|c|c|c|c|}
\hline & \multicolumn{7}{|c|}{ Over the past three months } & \multicolumn{7}{|c|}{ Over the next three months } & \multirow{2}{*}{$N / A^{(2)}$} \\
\hline & -- & - & $\circ$ & + & ++ & Mean & \begin{tabular}{|l|} 
Standard \\
deviation
\end{tabular} & -- & - & o & + & ++ & Mean & $\begin{array}{l}\text { Standard } \\
\text { deviation }\end{array}$ & \\
\hline \multirow{3}{*}{$\begin{array}{l}\text { A) Retail funding } \\
\text { Short-term deposits (up to one year) } \\
\text { Long-term (more than one year) deposits } \\
\text { and other retail funding instruments }\end{array}$} & & & & & & & & \multirow{3}{*}{$\begin{array}{l}0 \% \\
0 \%\end{array}$} & & & & & & & \multirow{3}{*}{$\begin{array}{l}10 \% \\
10 \% \\
\end{array}$} \\
\hline & $0 \%$ & $9 \%$ & $69 \%$ & $15 \%$ & $6 \%$ & 3.18 & 0.71 & & $9 \%$ & $75 \%$ & $15 \%$ & $2 \%$ & 3.10 & 0.58 & \\
\hline & $2 \%$ & $12 \%$ & $69 \%$ & $15 \%$ & $2 \%$ & 3.03 & 0.69 & & $11 \%$ & $77 \%$ & $12 \%$ & $0 \%$ & 3.01 & 0.51 & \\
\hline \multirow{3}{*}{$\begin{array}{l}\text { B) Inter-bank unsecured money market } \\
\text { Very short-term money market (up to one } \\
\text { week) } \\
\text { Short-term money market (more than one } \\
\text { week) }\end{array}$} & & & & & & & & \multirow{2}{*}{19} & & & & & & & \multirow{3}{*}{$\begin{array}{l}10 \% \\
10 \% \\
\end{array}$} \\
\hline & $0 \%$ & $7 \%$ & $80 \%$ & $10 \%$ & $4 \%$ & 3.10 & 0.58 & & $7 \%$ & $82 \%$ & $8 \%$ & $2 \%$ & 3.03 & 0.53 & \\
\hline & $2 \%$ & $9 \%$ & $76 \%$ & $11 \%$ & $2 \%$ & 3.01 & 0.63 & $1 \%$ & $7 \%$ & $81 \%$ & $11 \%$ & $0 \%$ & 3.02 & 0.48 & \\
\hline \multirow{3}{*}{$\begin{array}{l}\text { C) Wholesale debt securities }{ }^{(3)} \\
\text { Short-term debt securities (e.g. certificates } \\
\text { of deposit or commercial paper) } \\
\text { Medium to long-term debt securities (incl. } \\
\text { covered bonds) }\end{array}$} & & & & & & & & \multirow[b]{3}{*}{$3 \%$} & & & & & & & \multirow{3}{*}{$\begin{array}{l}19 \% \\
12 \% \\
\end{array}$} \\
\hline & $2 \%$ & $9 \%$ & $66 \%$ & $18 \%$ & $5 \%$ & 3.13 & 0.76 & & $8 \%$ & $71 \%$ & $19 \%$ & $2 \%$ & 3.13 & 0.63 & \\
\hline & $0 \%$ & $9 \%$ & $55 \%$ & $32 \%$ & $3 \%$ & 3.29 & 0.73 & & $6 \%$ & $65 \%$ & $25 \%$ & $1 \%$ & 3.15 & 0.69 & \\
\hline \multicolumn{8}{|l|}{ D) Securitisation ${ }^{(4)}$} & & & & & & & & \multirow[b]{2}{*}{$56 \%$} \\
\hline Securitisation of corporate loans & $0 \%$ & $16 \%$ & $73 \%$ & $11 \%$ & $0 \%$ & 2.95 & 0.57 & $1 \%$ & $13 \%$ & $72 \%$ & $15 \%$ & $0 \%$ & 3.01 & 0.61 & \\
\hline Securitisation of loans for house purchase & $0 \%$ & $10 \%$ & $79 \%$ & $11 \%$ & $0 \%$ & 3.01 & 0.50 & $1 \%$ & $8 \%$ & $75 \%$ & $17 \%$ & $0 \%$ & 3.07 & 0.57 & $53 \%$ \\
\hline $\begin{array}{l}\text { E) Ability to transfer credit risk off balance } \\
\text { sheet }{ }^{(5)}\end{array}$ & $5 \%$ & $11 \%$ & $72 \%$ & $10 \%$ & $1 \%$ & 2.90 & 0.75 & $5 \%$ & $11 \%$ & $78 \%$ & $5 \%$ & $0 \%$ & 2.84 & 0.68 & $60 \%$ \\
\hline
\end{tabular}

(1) Please also take into account any effect of state guarantees for debt securities and recapitalisation support.

(2) Please select "N/A" (not applicable) only if the source of funding is not relevant for your bank.

(3) Usually involves on-balance sheet funding.

(4) Usually involves the sale of loans from banks' balance sheets, i.e. off-balance sheet funding.

(5) Usually involves the use of credit derivatives, with the loans remaining on banks' balance sheets. 
ii. Given the tensions in the European sovereign debt market ${ }^{(1)}$, how have the following factors affected your bank's funding conditions/credit standards over the past three months?

\begin{tabular}{|l|c|c|c|c|c|c|c|}
\cline { 2 - 8 } \multicolumn{1}{c|}{} & \multicolumn{6}{c|}{ Impact on your bank's funding } \\
\cline { 4 - 9 } \multicolumn{1}{c|}{} & \multicolumn{7}{c|}{ conditions } \\
\cline { 3 - 8 } \multicolumn{1}{c|}{ A) Direct exposure to sovereign debt } & 3 & 9 & 83 & 5 & 0 & 3 & 1 \\
\hline $\begin{array}{l}\text { B) Value of sovereign collateral } \\
\text { available for wholesale market } \\
\text { transactions (2) }\end{array}$ & 3 & 14 & 77 & 7 & 0 & 3 & 1 \\
\hline C) Other effects (3) & 5 & 11 & 83 & 1 & 0 & 3 & 1 \\
\hline
\end{tabular}

\begin{tabular}{|c|c|c|c|c|c|c|c|c|c|c|c|c|c|c|c|c|c|c|c|c|c|}
\hline & \multicolumn{21}{|c|}{ Impact on your bank's credit standards } \\
\hline & \multicolumn{7}{|c|}{ Loans or credit lines to enterprises } & \multicolumn{7}{|c|}{ Loans to hous eholds for house purchase } & \multicolumn{7}{|c|}{$\begin{array}{l}\text { Loans to households for consumer credi } \\
\text { and other lending }\end{array}$} \\
\hline & -- & - & $=$ & + & ++ & Mean & $\mathrm{sd}$ & -- & - & $=$ & + & ++ & Mean & sd & -- & - & $=$ & + & ++ & Mean & sd \\
\hline A) Direct exposure to sovereign debt & 1 & 7 & 91 & 1 & 0 & 3 & 0 & 0 & 4 & 96 & 0 & 0 & 3 & 0 & 1 & 3 & 95 & 0 & 0 & 3 & 0 \\
\hline $\begin{array}{l}\text { B) Value of sovereign collateral } \\
\text { available for wholesale market } \\
\text { transactions (2) }\end{array}$ & 1 & 6 & 93 & 0 & 0 & 3 & 0 & 0 & 4 & 96 & 0 & 0 & 3 & 0 & 1 & 3 & 95 & 0 & 0 & 3 & 0 \\
\hline C) Other effects (3) & 1 & 6 & 93 & 0 & 0 & 3 & 0 & 0 & 6 & 94 & 0 & 0 & 3 & 0 & 2 & 4 & 94 & 0 & 0 & 3 & 0 \\
\hline
\end{tabular}

(1) Please also take into account any effect of state guarantees for debt securities and recapitalisation support.

(2) For example, repos or secured transactions in derivatives.

(3) For instance, any automatic rating downgrade affecting your bank following a sovereign downgrade or changes in the value of the domestic government's implicit guarantee, as well as spillover effects on other assets, including the loan book. 


\section{ANNEX 3: GLOSSARY}

To assist respondent banks in filling out the questionnaire, this glossary defines the most important terminology used in the bank lending survey:

\section{Capital}

In accordance with the Basel capital adequacy requirements, the definition of capital includes both tier 1 capital (core capital) and tier 2 capital (supplementary capital). In the context of the EU Capital Requirements Directive, Directive 2006/48/EC of the European Parliament and of the Council of 14 June 2006 relating to the taking up and pursuit of the business of credit institutions defines capital as own funds and makes a distinction between original own funds and additional own funds.

\section{$\underline{\text { Collateral }}$}

The security given by a borrower to a lender as a pledge for the repayment of a loan. This could include certain financial securities, such as equity or debt securities, real estate or compensating balances (a compensating balance is the minimum amount of a loan that the borrower is required to keep in an account at the bank).

\section{Consumer confidence}

Consumers' assessments of economic and financial trends in a particular country and/or in the euro area. They include assessments of the past and current financial situations of households and resulting prospects for the future, assessments of the past and current general economic situation and resulting prospects for the future, as well as assessments of the advisability of making residential investments (question 14), particularly in terms of affordability, and/or major purchases of durable consumer goods (question 15).

\section{$\underline{\text { Cost of funds and balance sheet constraints }}$}

A bank's capital and the costs related to its capital position can become a balance sheet constraint that may inhibit the expansion of its lending. For a given level of capital, the bank's loan supply could be affected by its liquidity position and its access to money and debt markets. Similarly, a bank could abstain from granting a loan, or be less willing to lend, if it knows that it will not be able subsequently to transfer the risk (synthetic securitisation) or the entire asset (true-sale securitisation) off its balance sheet. 


\section{Covenant}

An agreement or stipulation laid down in loan contracts, particularly contracts with enterprises, under which the borrower pledges either to take certain action (an affirmative covenant), or to refrain from taking certain action (a negative covenant); this is consequently part of the terms and conditions of the loan.

\section{Credit line}

A facility with a stated maximum amount that an enterprise is entitled to borrow from a bank at any given time. For the purposes of the survey, developments regarding credit lines should be interpreted as changes in the net amount that can be drawn down under either an existing or a new credit line.

\section{Credit standards}

The internal guidelines or criteria that reflect a bank’s lending policy. They are the written and unwritten criteria, or other practices related to this policy, which define the types of loan a bank considers desirable and undesirable, its designated geographical priorities, collateral deemed acceptable or unacceptable, etc. For the purposes of the survey, changes in written loan policies, together with changes in their application, should be reported.

\section{Credit terms and conditions}

These refer to the specific obligations agreed upon by the lender and the borrower. In the context of the bank lending survey, they consist of the direct price or interest rate, the maximum size of the loan and the access conditions, and other terms and conditions in the form of non-interest rate charges (i.e. fees), collateral requirements (including compensating balances), loan covenants and maturities (short-term versus long-term).

\section{Debt restructuring}

Debt restructuring is a relevant factor in the context of the bank lending survey only to the extent that it gives rise to an actual increase or decrease in demand for loans following the decision of corporations with outstanding debt obligations to alter the terms and conditions of these loans. Generally, companies use debt restructuring to avoid defaulting on existing debt or to take advantage of lower interest rates or lower interest rate expectations. In the context of this survey, debt restructuring should not be interpreted as the switching between different types of debt (such as MFI loans and debt securities; this is already captured under 
the item "Issuance of debt securities"), capital restructuring (substitution between debt and equity) or share buy-backs (already captured under the item "Issuance of equity"). Debt restructuring in the form of inter-company loans is already covered by the item "Loans from non-banks”. Moreover, debt restructuring in the form of a substitution between short-term and long-term loans does not give rise to a change in overall loan demand.

\section{Diffusion index}

The diffusion index is defined as the difference between the weighted sum of the percentages of banks responding "tightened considerably" and "tightened somewhat", and the weighted sum of the percentages of banks responding "eased considerably" and "eased somewhat”. Regarding demand for loans, the diffusion index is defined as the difference between the weighted sum of the percentages of banks responding "increased considerably" and "increased somewhat", and the weighted sum of the percentages of banks responding "decreased considerably" and "decreased somewhat". The diffusion index is weighted according to the intensity of the response, giving lenders who have answered "considerably" a weight twice as high (score of 1 ) as lenders having answered "somewhat" (score of 0.5).

\section{Enterprises}

The term "enterprises" denotes non-financial corporations, i.e. all private and public institutional units, irrespective of their size and legal form, which are not principally engaged in financial intermediation but rather in the production of goods and nonfinancial services.

\section{Enterprise size}

The distinction between large enterprises and small and medium-sized enterprises is based on annual sales. An enterprise is considered large if its annual net turnover is more than $€ 50$ million.

\section{Households}

Individuals or groups of individuals acting as consumers or as producers of goods and non-financial services exclusively intended for their own final consumption, as well as small-scale market producers. 


\section{Housing market prospects}

In question 9, (besides interest rate developments) "housing market prospects” refers to the risk on the collateral demanded; in question 14, it includes households' expectations regarding changes in house prices.

\section{Loans}

The loans covered by the bank lending survey are those granted to euro area residents by domestic bank branches, and include loans or credit lines to enterprises, loans to households for house purchase, and consumer credit and other lending to households.

\section{Loan-to-value ratio}

The ratio of the amount borrowed to the appraisal or market value of the underlying collateral, usually employed in relation to loans used for real estate financing.

\section{Maturity}

Maturity as used in the bank lending survey is original maturity, and only two types are used: short-term and long-term. Short-term loans are loans with an original maturity of one year or less; long-term loans have an original maturity of more than one year.

\section{Net percentage (or balance)}

In the context of credit standards, the net percentage is defined as the difference between the sum of the percentages of banks responding "tightened considerably" and "tightened somewhat", and the sum of the percentages of banks responding "eased considerably" and "eased somewhat". Regarding demand for loans, the net percentage is defined as the difference between the sum of the percentages of banks responding "increased considerably" and "increased somewhat", and the sum of the percentages of banks responding “decreased considerably” and “decreased somewhat”.

\section{Non-banks}

In general, these consist of non-monetary financial corporations, in particular insurance corporations and pension funds, financial auxiliaries and other financial intermediaries. 


\section{Non-interest rate charges}

Various kinds of fees that can form part of the pricing of a loan, such as commitment fees on revolving loans, administration fees (e.g. document preparation costs), and charges for enquiries, guarantees and credit insurance. 